\title{
Deep segregation in the open ocean: Macaronesia as an evolutionary hotspot for low dispersal marine invertebrates
}

Vieira, Pedro E.; Desiderato, Andrea; Holdich, David M.; Soares, Pedro; Creer, Simon; Carvalho, Gary; Costa, Filipe O.; Queiroga, Henrique

\section{Molecular Ecology}

DOI:

$10.1111 / \mathrm{mec} .15052$

Published: 01/04/2019

Peer reviewed version

Cyswllt i'r cyhoeddiad / Link to publication

Dyfyniad o'r fersiwn a gyhoeddwyd / Citation for published version (APA):

Vieira, P. E., Desiderato, A., Holdich, D. M., Soares, P., Creer, S., Carvalho, G., Costa, F. O., \& Queiroga, H. (2019). Deep segregation in the open ocean: Macaronesia as an evolutionary hotspot for low dispersal marine invertebrates. Molecular Ecology, 28(7), 1784-1800. https://doi.org/10.1111/mec.15052

\footnotetext{
Hawliau Cyffredinol / General rights

Copyright and moral rights for the publications made accessible in the public portal are retained by the authors and/or other copyright owners and it is a condition of accessing publications that users recognise and abide by the legal requirements associated with these rights. study or research.

dhe public portal for the purpose of private

- You may not further distribute the material or use it for any profit-making activity or commercial gain

- You may freely distribute the URL identifying the publication in the public portal ?
}

Take down policy

If you believe that this document breaches copyright please contact us providing details, and we will remove access to the work immediately and investigate your claim. 

dispersal marine invertebrates.

3

4 Pedro E Vieira ${ }^{1,2,3}$, Andrea Desiderato ${ }^{4,5}$, David M Holdich ${ }^{6}$, Pedro Soares $^{2,7}$, Simon Creer $^{3}$, 5 Gary R Carvalho ${ }^{3}$, Filipe O Costa ${ }^{2,7}$, Henrique Queiroga ${ }^{1}$

$6{ }^{1}$ Departamento de Biologia and CESAM - Centro de Estudos do Ambiente e do Mar, 7 Universidade de Aveiro, 3810-193 Aveiro, Portugal

$8{ }^{2}$ CBMA - Centro de Biologia Molecular e Ambiental, Departamento de Biologia, Universidade 9 do Minho, 4710-057 Braga, Portugal

${ }^{3}$ Molecular Ecology \& Fisheries Genetics Laboratory, School of Biological Sciences, Bangor University, Bangor, Wales, UK ${ }^{4}$ Programa de Pós-graduação em Zoologia (PGZOO), Universidade Federal do Paraná, CP 19020, Curitiba, Paraná 81531-980, Brazil

${ }^{5}$ Alfred Wegener Institute, Helmholtz Centre for Polar and Marine Research, Department of Functional Ecology, Am Handelshafen 12, 27570 Bremerhaven, Germany

${ }^{6}$ Aquatic Consultant, Keyworth, Nottinghamshire, England, UK

${ }^{7}$ Institute of Science and Innovation for Bio-Sustainability (IB-S), University of Minho, Portugal

\section{Corresponding author}

Pedro E Vieira

pedroefrvieira@gmail.com

https://orcid.org/0000-0003-4880-3323

\section{Running head}

Deep segregation in Macaronesian marine fauna 


\section{Abstract}

Diversification and speciation of terrestrial organisms is anticipated in oceanic islands such as Macaronesia, a group of Atlantic islands that have remained unconnected to continental landmasses. Hitherto, the diversification of marine organisms in oceanic islands, especially those with low vagility, has received little direct empirical analysis using molecular markers. Here, we focus on such a case study, through applying a multi-locus molecular approach to investigate the diversity and evolution of a group that lacks a planktonic larval stage, the isopod genus Dynamene, in Macaronesia and Northeast Atlantic. Sequences of two mitochondrial (cytochrome c oxidase subunit I and 16S rRNA) and two nuclear (18S rRNA and 28S rRNA) loci were obtained from specimens of Dynamene edwardsi (Lucas, 1849), Dynamene magnitorata Holdich, 1968 and Dynamene bidentata (Adams, 1800) collected along the Northeast Atlantic and Macaronesia. Although no major phylogeographic structure was detected in $D$. bidentata and $D$. magnitorata, from five to nine deeply divergent lineages were evident within $D$. edwardsi. The divergent lineages displayed genetic distances comparable to those found among established species of peracarids. Dynamene edwardsi exhibits a long, rich and complex phylogeographic history in Macaronesia, where the geodynamics of the islands possibly associated with founder effects and subsequent lack of gene flow among populations, confounds patterns based on geographical proximity of targeted populations. Our findings collectively suggest a much larger role of oceanic islands in the diversification of marine invertebrates than previously anticipated. The work provides insights into the origins and dynamics of ongoing geographic segregation and associated deep divergence among sister evolutionary lineages in Macaronesia.

\section{Keywords}

Dynamene, Macaronesia, cryptic species, oceanic islands, endemism, Northeast Atlantic. 


\section{Introduction}

Islands have always caught the attention of researchers as ideal and unique natural laboratories to study evolutionary and phylogeographic processes (Emerson, 2002; Valente, Etienne, \& Phillimore, 2014). Some archipelagos are notorious for the biodiversity they harbor, such as the Galapagos where Darwin (1859) recorded the occurrence of extensive levels of endemic taxa. Another famous group of islands, associated with unique biodiversity, is Macaronesia; a group of oceanic archipelagos of volcanic origin in the North Atlantic (Azores, Madeira, Canaries and Cabo Verde) that have distinct geneses and geological timelines. For instance, Selvagens emerged more than 25 million years (Myr) ago, Gran Canaria and Porto Santo around 15 Myr, while El Hierro and some islands of Azores appeared less than $1.5 \mathrm{Myr}$ (for details of origin and geological times of each island and archipelago, see Carine \& Schaefer, 2010; Fernández-Palacios et al., 2011; Geldmacher, Hoernle, Bogaard, Duggen, \& Werner, 2005; Geldmacher, Hoernle, Bogaard, Zankl, \& Garbe-Schönberg, 2001). Moreover, Macaronesian islands experience a wide range of climatic conditions and possess a highly diverse marine biota that have experienced dynamic geological and climatic changes over relatively long periods (e.g., Pleistocene glaciations; Fernández-Palacios, 2016; FernándezPalacios et al., 2016; Norder et al., 2018). Because Macaronesian archipelagos have never been connected to the mainland, their biota is the result of dispersal from distant geographical sources and in situ diversification (Fernández-Palacios et al., 2011). Macaronesia therefore provides an ideal, yet understudied system to investigate evolution and phylogeography in marine benthic organisms with limited dispersal capacity (Maggs et al., 2008; Wares \& Cunningham, 2001).

While patterns of diversification in Macaronesia, mainly in terrestrial organisms, have been reviewed by Borregaard et al. (2017), colonization and gene flow of marine benthic organisms have only been studied in those with a pelagic phase (Chevolot, Hoarau, Rijnsdorp, Stam, \& Olsen, 2006; Sá-Pinto, Branco, Sayanda, \& Alexandrino, 2008; Xavier, van Soest, Breeuwer, Martins, \& Menken, 2010). Marine benthic invertebrates that inhabit intertidal coastal areas are 
unique relative to both terrestrial organisms and other marine taxa (Hachich et al., 2015). Many intertidal species have pelagic larvae which may promote dispersal over open water, potentially circumventing habitat discontinuity (Grantham, Eckert, \& Shanks, 2003; Scheltema, 1986). However, some small invertebrates, such as free-living isopods, are more prone to isolation due to life histories characterised by direct development and putatively reduced vagility, compared to other marine species with pelagic larvae (Thiel \& Gutow, 2005). Longdistance dispersal may occur through random events such as transport by shipping (Rumbold et al., 2018) or by rafting on detached macroalgae or floating debris (Thiel \& Gutow, 2005). Effective recruitment following such mechanisms is, however, typically low due to high mortality and competition in the new habitat (Highsmith, 1985; Thiel \& Gutow, 2005).

Understanding the diversity of such organisms can be hampered either by lack of comprehensive data on species distribution, i.e., the Wallacean shortfall (e.g., Cardoso, Erwin, Borges \& New, 2011) or the lack of relevant phylogenetic information, i.e., the Darwinian shortfall (e.g., Diniz-Filho, Loyola, Raia, Mooers \& Bini, 2013). In addition, it may be difficult to describe species based solely on morphological characters (Beheregaray \& Caccone, 2007; Fišer, Robinson, \& Malard, 2018; Knowlton, 1993). In peracarids, for example, even familylevel diagnostic characters can change with development and sex, making identification problematic (Larsen, 2001; Larsen \& Wilson, 1998). Such ambiguity is enhanced further by the occurrence of cryptic species, as for example among different terrestrial organisms in Macaronesia (e.g., Borges et al., 2017; López, Hernández-Teixidor, Macías-Hernández, Juan \& Oromí, 2013) and in marine organisms elsewhere (Miglietta, Faucci, \& Santini, 2011), especially among those with reduced vagility (Cook, Page, \& Hughes, 2008; Knowlton, 1993). In order to resolve taxonomic ambiguity, molecular taxonomy has been successfully applied to isopods. Examples include the validation of new species (Khalaji-Pirbalouty \& Raupach, 2014; Xavier et al., 2011), discrimination of morphologically similar species (Radulovici et al., 2009; Xavier et al., 2012) or unravelling multiple cryptic species complexes (Brix, Svavarsson, 
\& Leese, 2014; Markow \& Pfeiler, 2010; Raupach et al., 2014; Raupach \& Wägele, 2006; Varela \& Haye, 2012).

The existence of cryptic species is suspected, though not yet investigated, within most of the large genera in the isopod family Sphaeromatidae such as Cilicaea, Cymodoce, Dynamenella, Exosphaeroma, Pseudosphaeroma and Dynamene (Poore \& Bruce, 2012). Members of the genus Dynamene Leach, 1814 are common and abundant on rocky intertidal and shallow subtidal habitats of the Northeast (NE) Atlantic Ocean, Mediterranean and Black Seas. Although eight Dynamene species were reported worldwide (six in the Northern Hemisphere), only three species are present in the NE Atlantic (Holdich, 1970; Vieira, Queiroga, Costa, \& Holdich, 2016): D. bidentata (Adams, 1800), D. edwardsi (Lucas, 1849) and D. magnitorata Holdich, 1968. Consequently, in this study, we aim to exploit an ideal opportunity to investigate the role of Macaronesian islands in shaping the phylogeography and evolutionary history of marine invertebrates lacking a pelagic dispersal stage. We examine the genetic diversity and phylogeography of Dynamene morphospecies from the Macaronesian archipelagos of Azores, Madeira and Canaries in the NE Atlantic using a multi-locus approach, and reveal an evolutionary history of extensive radiation followed by long-term lineage segregation, which would not be anticipated in an island-dwelling marine invertebrate.

\section{Material and Methods}

\section{Specimen sampling and taxonomic identification}

127 Specimens were collected in the NE Atlantic (Vieira, Queiroga, Costa, \& Holdich, 2016) between 2009 and 2015 among algae in the rocky shore intertidal (Figure 1; Table S1). Three species were sampled: $D$. bidentata, $D$. magnitorata and $D$. edwardsi. Dynamene bidentata was collected in Scotland, the Iberian Peninsula, Morocco and Gran Canaria (Figure 1; Table S1); D. magnitorata was found in the Iberian Peninsula, Morocco and in the islands of Santa Maria, Terceira, São Miguel and La Palma (Figure 1; Table S1) and D. edwardsi in the Iberian Peninsula, Madeira, Porto Santo, Selvagens, Gran Canaria, La Palma, Tenerife, El Hierro, 
São Miguel and Morocco (Figure 1; Table S1). Two additional individuals sampled in 2014 (see Acknowledgements) from algae present at $1 \mathrm{~m}$ depth in two harbors from the Mediterranean were also incorporated, one from France and another from Croatia (Figure 1; Table S1). A detailed interactive map can be accessed at https://rpubs.com/Vieira/DynameneSamplingLocations, in which the sampling locations and the distances between them can be observed for each Dynamene species. The interactive map was created with the package 'leaflet' (Cheng, Karambelkar, \& Xie, 2018), through the software R 3.5.0 (R core team 2018; www.r-project.org).

After collection, specimens were immediately preserved in $96 \%$ ethanol. Morphology-based taxonomic identification was supported by specialized literature (Holdich, 1968a; Vieira, Queiroga, Costa, \& Holdich, 2016) and David Holdich, a recognized expert in Dynamene taxonomy (e.g., Holdich, 1968a, 1968b, 1976), confirmed the classification of the specimens used in the analyses and their assignment to morphospecies. Identifications were reviewed before and after obtaining the DNA sequences to ensure correct identification of the specimens. A total of 2815 Dynamene specimens were observed morphologically (1144 D. edwardsi specimens, 497 D. bidentata specimens and 1174 D. magnitorata individuals). A complete and detailed list of the material observed (and other Dynamene specimens/species) by David Holdich and/or Pedro Vieira can be consulted in Vieira, Queiroga, Costa, \& Holdich (2016) Supplementary material 1. Representative specimens from each location were deposited in the CESAM Biological Research Collection of Marine Invertebrates (Aveiro, Portugal) under the accession number DBUA0002261- DBUA0002273.

Scanning electron microscope images were produced for one representative adult male for each species by David Holdich whilst at the University of Nottingham - see Holdich (1976) for details of preparation and equipment used. The Dynamene bidentata adult male was collected in a mid-shore crevice at St Brides Haven, Wales, in October 1965. The Dynamene magnitorata adult male was also collected in a mid-shore crevice, at Roscoff, France, in April 1966. The Dynamene edwardsi adult male was collected amongst tube worms at $1 \mathrm{~m}$ depth in 
Naples, Italy, in June 1967. The specimens of the three species no longer exist as they had been dried for the SEM work in 1976. Consequently, no accession numbers are available.

\section{$\underline{D N A}$ extraction, amplification and sequencing}

DNA was extracted using the E.Z.N.A. Mollusc DNA extraction Kit according to manufacturer's instructions. Depending on specimen size, only a small amount of tissue (pereopods or/and part of the pereon) or the whole animal was used. We used the cytochrome c oxidase subunit I (COI) DNA barcode region as the primary locus for investigating the genetic diversity of Dynamene. A total of 179 sequences were obtained (40 for D. bidentata, 101 for $D$. edwardsi and 38 for D. magnitorata; Table S1). Based on the COI phylogeny we selected representative specimens from each geographic region and species for further sequence analysis using part of the mitochondrial gene 16s rRNA $(\mathrm{N}=43)$, a partial segment of the nuclear gene coding for 28s rRNA ( $\mathrm{N}=46)$ and the variable regions $2-5$ of 18 s rRNA $(\mathrm{N}=120)$. All PCR reactions were performed in a total of $25 \mu \mathrm{l}$ volume, containing $12.5 \mu \mathrm{l}$ supreme Taq (Nzytech), 0.5-1.25 $\mu \mathrm{l}$ of each primer $(10 \mathrm{mM})$ and 1-4 $\mu$ I DNA extraction. The remaining volume comprised ultrapure water. PCR conditions and primers used are detailed in Table S2.

A 658-base pair (bp) region of COI was amplified using LoboF1/LoboR1 (Lobo et al., 2013) or LCO1490/HCO2198 (Folmer, Black, Hoeh, Lutz, \& Vrijenhoek, 1994) primers, and a fragment of 16S rRNA was amplified using 16Sar/16Sbr (Palumbi et al., 2002) or D16SAR/D16SBR (Geller, Walton, Grosholz, \& Ruiz, 1997) primers depending on PCR reaction success. The nuclear genes coding 18S rRNA were amplified with the primers 18sAi/18sBi (Whitting, 2002) and 28S rRNA with the primers AM-28S-H/AM-28S-T (Tomikawa, Kobayashi, Morino, \& Mawatari, 2007). Amplification success was verified in a 1.5\% agarose gel. PCR products were purified (with Roche purification kit according to manufacturer instructions) and sequenced bidirectionally by an external service supplier (STABVida), using an ABI 3730 sequencer and following standard chain-termination sequencing protocols.

\section{Data analysis}


All sequences were analysed and edited using MEGA 7.0 (Kumar, Stecher, \& Tamura, 2016). Trace files were checked manually; unreadable zones and primers were removed and ambiguous bases corrected. For the $658 \mathrm{bp} \mathrm{COI}$ region, the edited sequences were aligned using Clustal W (Thompson, Higgins, \& Gibson, 1994) as implemented in MEGA 7.0 (Kumar, Stecher, \& Tamura, 2016) and the translation verified for stop codons or indels.

Sequences of $16 \mathrm{~S}$ rRNA, 18S rRNA and $28 \mathrm{~S}$ rRNA were aligned separately using Clustal W (Thompson, Higgins, \& Gibson, 1994) tool in MEGA 7.0 (Kumar, Stecher, \& Tamura, 2016). Highly variable regions were deleted from the analysis using Gblocks $0.91 \mathrm{~b}$ (http://molevol.cmima.csic.es/castresana/Gblocks_server.html; Castresana, 2000). Alignment using Clustal W and subsequent removal of poorly aligned positions and divergent regions in rRNA sequences is advisable so that it becomes more suitable for phylogenetic analysis (Castresana, 2000; Talavera \& Castresana, 2007).

\section{Phylogenetic analyses}

Phylogenetic analyses for each locus and for the concatenated data (merged together in DNASP 5.10; Librado \& Rozas, 2009), were performed using maximum likelihood (ML) and Bayesian inference (BI). The software MEGA 7.0 (Kumar, Stecher, \& Tamura, 2016) was used to determine the best model of evolution (ML based on AICc information and BI based on BIC information; see Table S3 for list of models). The ML tree was reconstructed using PhyML 3.0 (Guindon et al., 2010; http://www.atgc-montpellier.fr/phyml/). Branch support was estimated using 1,000 bootstrap replicates. The Bayesian tree was built using MrBayes on XSEDE 3.2.6 (Ronquist et al., 2012) through the CIPRES Science Gateway (Miller, Pfeiffer, \& Schwartz, 2010). Two independent runs were conducted with $200,000,000$ generations each. Parameters were sampled every 1,000 generations. In the end, a majority rule consensus tree was reconstructed with a burn-in of $25 \%$ and the convergence checked (close to or equal to 1 ). Haplotype genealogy was investigated by building median networks for COI, 16S rRNA, 18S rRNA and 28S rRNA data using the reduced median algorithm (Bandelt, Forster, Sykes, \& Richards, 1995) in Network 5.0.0.3 (http://www.fluxus-engineering.com). 
216 Five methods of molecular-based species delineation were applied to define molecular operational taxonomic unit (MOTUs). They were applied to each locus and to the concatenated data, except for the BIN system that relies only on COI. The first two methods were based on distance measures. First, $\mathrm{COI}$ sequences were automatically subject to the BIN system implemented in BOLD. This approach clusters barcode sequences algorithmically to calculate MOTUs that show high concordance to species (Ratnasingham \& Hebert, 2013). Then, the Automatic Barcode Gap Discovery (ABGD) species delineation tool on a web interface (http://wwwabi.snv.jussieu.fr/public/abgd/abgdweb.html) was applied with default settings using the Kimura-2-parameter (K2P) distance matrix. This tool, based on the barcode gap detection (i.e., break between the distribution of intraspecific and interspecific distances of the barcode region), sorts the sequences into hypothetical species (Puillandre, Lambert, Brouillet, \& Achaz, 2012). Finally, three tree-based methods were applied: GMYC (Generalized Mixed Yule Coalescent) single and multi-threshold models (Fujisawa \& Barraclough, 2013) and bPTP (Poisson Tree Processes; Zhang, Kapli, Pavlidis, \& Stamatakis, 2013). The GMYC method is based on the examination of the branching patterns in an ultrametric tree, and the recognition of the transitions from branching patterns attributable to speciation (one lineage per species) to those that can be attributed to intra-species coalescent process (multiple lineages per species). We applied both the single threshold (Pons et al., 2006) and multiple thresholds (Monaghan et al., 2009) variants of this method. Since the GMYC methods require an ultrametric tree, we first calculated a Bayesian ultrametric phylogenetic tree. The tree was generated in BEAST 2.4.6 (Bouckaert et al., 2014) with the appropriate best model (based on BIC criteria; Table S3), and four independent runs for 70,000,000 Markov chain Monte Carlo (MCMC) generations, sampled every 10,000 generations, were performed. Effective sampling sizes (ESSs > 200 for all parameters) and convergence of the parameter estimates were evaluated using Tracer 1.6 software (Rambaut, Suchard, Xie, \& Drummond, 2014). The consensus tree was annotated using TreeAnnotator 2.4.6 (Bouckaert et al., 2014). The 
consensus tree was loaded into the R software package 'SPLITS' (Species Limits by Threshold

243 Statistics; Ezard, Fujisawa, \& Barraclough, 2009) through the software R 3.5.0 (R core team 2018; www.r-project.org) and analysed using the single- and multiple-threshold models. The bPTP method incorporates the number of substitutions in the model of speciation and assumes that the probability that a substitution gives rise to a speciation event follows a Poisson distribution. The branch lengths of the input tree are supposed to be generated by two independent Poisson process classes, one corresponding to speciation and the other to coalescence (Zhang, Kapli, Pavlidis, \& Stamatakis, 2013). In contrast to GMYC, bPTP uses non-ultrametric phylograms. For the input tree, we used the ML phylogenies (for each locus and for the concatenated data) obtained above. Species delimitation analysis was performed using the python code available at: www.exelixis-lab.org/software.html (Zhang, Kapli, Pavlidis, \& Stamatakis, 2013) with 1,000,000 iterations of MCMC and $25 \%$ burn-in.

\section{Genetic diversity and structure}

Mean and maximum pairwise distances (p-distances) were calculated across the 16S rRNA, 18S rRNA and 28S rRNA loci after the application of Gblocks for each species (intraspecific distances) using MEGA 7.0 (Kumar, Stecher, \& Tamura, 2016). Additionally, p-distances for $\mathrm{COI}$ and 16S rRNA (after the application of Gblocks) within and between MOTUs were also calculated in MEGA 7.0 (Kumar, Stecher, \& Tamura, 2016). Indices of genetic diversity, namely haplotype diversity $(h)$ and nucleotide diversity $(\pi)$, were estimated for each locus and for each species and MOTU using DNASP 5.10 (Librado \& Rozas, 2009).

Using the COI data, Fst estimations were made in Arlequin 3.5 (Excoffier \& Lischer, 2010). Significance of pairwise Fst values was determined by performing 10,000 permutations between locations, under the null hypothesis of no differentiation. Locations with less than three individuals were excluded from the Fst analyses. Analysis of molecular variance (AMOVA) was performed in Arlequin 3.5 (Excoffier \& Lischer, 2010) to assess the population structure of each species. 
Different phylogeographic and demographic evolutionary scenarios were tested using the $R$

(Matzke,

2013a;

https://cran.r-

project.org/web/packages/BioGeoBEARS/index.html; for detailed information, methodology and associated packages see Matzke, 2013b, 2014) through the software R 3.5.0 (R core team 2018; www.r-project.org). Since this tool relies on a tree with only one representative sequence per lineage, we selected randomly one sequence per MOTU to build the input tree in MEGA 7.0 (Kumar, Stecher, \& Tamura, 2016), consisting on a concatenated ML tree based on the GTR+G+l substitution model and using 1,000 bootstraps.

In order to test for a model of isolation by distance we applied a Mantel test to Fst (as a genetic distance measure) between regions and geographical distance matrices on the IBDWS web interface (http://ibdws.sdsu.edu/ ibdws/distances.html; Jensen, Bohonak, \& Kelley, 2005). Geographic distances were accessed through the GeoDataSource platform (www.geodatasource.com/distance-calculator).

\section{Estimation of approximate time of divergence}

Phylogenetic reconstruction and age estimates of the different clades were also performed in BEAST 2.4.6 (Bouckaert et al., 2014) using COI data. We used both a relaxed molecular clock (uncorrelated lognormal) and a strict clock with an HKY85 model of molecular evolution (Table S3) and gamma distributed rates (10 gamma categories). The analyses ran for a total of $50,000,000$ states in the Markov chain. Effective sampling sizes (ESSs > 200 for all parameters) and convergence of the parameter estimates were evaluated using Tracer 1.6 software (Rambaut, Suchard, Xie, \& Drummond, 2014). The consensus tree was annotated using TreeAnnotator 2.4.6 (Bouckaert et al., 2014). The COI divergence rate has not been previously estimated for Dynamene species. However, there are estimates for other isopods: 2.5\% per Myr for Stenasellus (Ketmaier, Argano, \& Caccone, 2003) and Asellus (Konec, Prevorčnik, Sarbu, Verovnik, \& Trontelj, 2015; Verovnik, Sket, \& Trontelj, 2005) and 1.56 $1.72 \%$ per Myr for Orthometopon (Poulakakis \& Sfenthourakis, 2008). Because there is not an available fossil for Dynamene for calibration of the molecular clock, we selected five normally 
distributed priors for the age estimation and the calibration of the rate of evolution. One of the priors was the evolutionary rate itself that we centered at $2 \%$ with a $95 \%$ confidence interval ranging from $1.5 \%$ to $2.5 \%$ representing the lowest and the highest estimated $\mathrm{COI}$ rates in isopods in the literature (Ketmaier, Argano, \& Caccone, 2003; Konec, Prevorčnik, Sarbu, Verovnik, \& Trontelj, 2015; Poulakakis \& Sfenthourakis, 2008; Verovnik, Sket, \& Trontelj, 2005). These rates were also applied successfully by Xavier et al. (2012) and Panova, Nygren, Jonsson, \& Leidenberger (2016) in other two isopod genera (Stenosoma and Idotea respectively) and fit within the range of $\mathrm{COI}$ rates estimated for other marine arthropods (Knowlton \& Weigt, 1998; Markow \& Pfeiler, 2010; Sponer \& Lessios, 2009; Wares \& Cunningham, 2001). The second and third priors were based on the hypotheses that $D$. edwardsi colonized La Palma (formed at around 1.7 Myr; Fernández-Palacios et al., 2011; Guillou, Carracedo, \& Duncan, 2001) and El Hierro (1.1 Myr; Carracedo, 2011; FernándezPalacios et al., 2011) shortly after the formation of the islands, as used by Machado, Rodríguez-Expósito, López, \& Hernández (2017). The corresponding clades were set to priors of 1.7 Myr (standard error of $0.17 \mathrm{Myr}$ ) and 1.1 Myr (standard error of $0.11 \mathrm{Myr}$ ). A normal distribution fits the hypotheses as the colonization by $D$. edwardsi could have occurred after the islands' formation, or the clades could also be older as the first settlers could have already carried ancestral polymorphisms. The fourth and fifth priors were based on paleontological records, namely on data inferred from isopod fossils. No direct fossil evidence could be found for the Dynamene genus, nor for any member of the family Sphaeromatidae. However, Lins, Ho, Wilson, \& Lo (2012) were able to use isopod fossils (from deep-sea habitats) and molecular data (COI and 18s rRNA) to estimate the timing of colonization events of several isopod species. Based on their calculations, we were able to estimate the divergence between the Dynamene genus' sister clades Campecopea hirsuta and C. lusitanica (102 Myr; 95\% Cl [35$175 \mathrm{Myr}]$ ) and between Sphaeroma serratum and Lekanesphaera hookeri (75 Myr; 95\% Cl [25-135 Myr]), setting up the prior standard error in a way that the 95\% confidence interval would fit the above. Because these estimates are less accurate and have wide confidence 
intervals, we assessed the effect of the different calibration points applying the relaxed clock under three settings: using only the rate of evolution, using both islands' colonization priors, and using both fossil-based estimates. Results were generated considering a burn-in of $10 \%$ and $25 \%$. Detailed information regarding the species and outgroups used in the phylogenetic reconstruction and age estimates can be consulted in Table S4.

\section{Results}

\section{Morphological analysis}

Morphologically, D. edwardsi, D. bidentata and $D$. magnitorata are relatively easy to discriminate among adult males, but harder to separate between sub-adult males, juveniles and females (Holdich, 1968a; Vieira, Queiroga, Costa, \& Holdich, 2016). Figure 2 shows scanning electronmicrographs of the three species and highlights diagnostic morphological characters. The main morphological difference is in the form of the pleotelsonic boss (thinner arrows), which in $D$. edwardsi is an upright cleft plate with peg-like structures at the corners (Figure 2a, b). In $D$. bidentata it is bilobed and the two halves are separated by a wide v-shaped groove (Figure 2c, d). In D. magnitorata the pleotelsonic boss is also bilobed, but the two halves are more angular and separated by a narrow groove (Figure $2 \mathrm{e}, \mathrm{f}$ ). Also important is the shape of the arms of the bidentate process (thicker arrows), which arises from the posterior margin of the sixth pereonite - a feature unique amongst sphaeromatid isopods. In $D$. edwardsi the end of each arm has a downwardly-directed spur (Figure 2a), whilst that of $D$. bidentata tapers to a point (Figure 2c), and that of $D$. magnitorata is more tuberculate and ends bluntly (Figure 2e). No stable morphological differences in the known diagnostic traits were found among individuals of the same species between different locations.

\section{Molecular analyses and MOTUs delimitation}

A total of 179 sequences of COI, 43 of $16 \mathrm{~S}$ rRNA, 120 of $18 \mathrm{~S}$ rRNA and 46 of $28 \mathrm{~S}$ rRNA were obtained for the three Dynamene species (Table S1). After the use of Gblocks, 16S rRNA, 18S rRNA and 28S rRNA comprised, respectively for each species: D. bidentata (458 bp, $1120 \mathrm{bp}$, 
781 bp); D. edwardsi (451 bp, 1084 bp, 801 bp) and D. magnitorata (426 bp, 1125 bp, 780 bp). All loci (individually and concatenated) discriminated the three species (Figures S1-5) and the $\mathrm{BI}$ and $\mathrm{ML}$ analyses produced similar topologies. Consequently, we present the $\mathrm{BI}$ tree with posterior probabilities from each analysis, complemented with ML bootstrap support (Figures S1-5). Dynamene edwardsi showed higher values of intraspecific variance (Table 1) and genetic diversity indices (Table S5) compared with $D$. bidentata or $D$. magnitorata, regardless of the locus used.

The total number of MOTUs obtained varied between 7 and 20 depending on the locus and delimitation method applied (Figure 3 for COI data; Figures S2-5 only show consensus MOTUs for the other loci and for the concatenated data). Dynamene edwardsi displayed the highest number of MOTUs (between 5 and 11), followed by $D$. magnitorata (between 1 and 5 ) and $D$. bidentata (between 1 and 4). To simplify further analyses, a consensus number of MOTUs was decided based on the majority rule (i.e., most common number of MOTUs across different delimitation methods for each locus and for the concatenated data). The consensus number of MOTUs for COI was 12 (Figure 3), for 16S rRNA was 7 and 12 (a tie; Figure S2), for $18 \mathrm{~S}$ rRNA was 9 (Figure S3), for 28S rRNA was 8 (Figure S4) and for the concatenated data was 11 and 13 (a tie; Figure S5). Delimitation methods applied to COI and the concatenated data identified the same MOTUs within $D$. edwardsi and $D$. bidentata, but not within $D$. magnitorata ( 2 using $\mathrm{COI}$ and between 1 and 3 using concatenated data). Because extensive evidence indicates that $\mathrm{COI}$ among the four markers, is the one that better reflects species boundaries (Grabowski, Wysocka, \& Mamos, 2017; Jörger, Norenburg, Wilson, \& Schrödl, 2012; Jörger \& Schrödl, 2013), we considered the value of 12 MOTUs the most plausible, partitioned into 9 MOTUs for D. edwardsi, 2 for $D$. magnitorata and 1 for $D$. bidentata (Figure 3). We consider this number of MOTUs as the most plausible and robust, given the data (the number delimited 374 study. 
375 All MOTUs showed low intraspecific genetic variance $(<1 \%)$ but high genetic distance between

376 different MOTUs $(2.02-23.55 \%$ for $\mathrm{COI}$ and $0.40-30.02 \%$ for $16 \mathrm{~S}$ rRNA; Table 2$)$. Within $D$.

377 edwardsi and D. magnitorata, the individual MOTUs were exclusive to specific regions and, in

378 several instances, single islands (Table S1). MOTU 2 (D. edwardsi) displayed the highest value

379 of nucleotide diversity, and MOTU 11 (D. magnitorata) had the highest values of haplotype 380 diversity and segregating sites. MOTUs 3 (D. edwardsi) and 12 (D. magnitorata) were unique in displaying single haplotypes (Table S5), with the latter being the only singleton retrieved in our analyses.

\section{Phylogeographic structure}

Results of the AMOVA (Table S6) showed that most of the variation within each species was among geographic regions. Here, we show the best geographic region partitioning that retrieved the highest values of variation for each Dynamene species. In D. edwardsi, $98.14 \%$ of the variation is explained by the genetic differentiation between the following 12 geographic regions: Iberian Peninsula (which includes Galicia, Portugal West and Portugal South), Morocco North, Morocco South, Mediterranean (which includes France and Croatia), São Miguel, Porto Santo, Madeira, Selvagens, Tenerife, Gran Canaria, La Palma and El Hierro (Table S6). Observed pairwise Fst values among locations (from different regions) were generally high, showing significant differentiation between regions (Table S7). In $D$. magnitorata, the variation was best explained by the differentiation among the geographic regions of Iberian Peninsula (which includes Galicia, Portugal West and Portugal South), Azores (which includes Terceira, São Miguel and Santa Maria) and La Palma; while the Fst values were higher than 0.6 between locations from different regions (Iberian Peninsula and Azores), but less than 0.4 between locations within these regions. The AMOVA of $D$. bidentata data yielded highest variation (67.58\%) between the geographic regions: Iberian Peninsula (which includes Galicia, Portugal West and Portugal South), Scotland, Morocco North and 
401

402

403

404

405

406

407

408

409

410

411

412

413

414

415

416

417

418

419

420

421

422

423

424

425

426

427

Peninsula, Scotland and Morocco) were higher than 0.6 and lower than 0.3 between locations within each region (Table S7).

Networks of the three species (Figure 1; Figure S6) supported the AMOVA results and clearly discriminated the same populations, with no shared haplotypes among regions. Moreover, the networks (for each locus) displayed similar topologies, thereby reinforcing the closer genetic similarity within $D$. magnitorata and $D$. bidentata compared to $D$. edwardsi.

The analysis of the dispersal method with BioGeoBEARS was only possible for $D$. edwardsi, because the method uses trees with clearly discriminated lineages, which did not occur in $D$. magnitorata and $D$. bidentata. The most probable model retrieved was DIVALIKE+J, which comprises a likelihood interpretation of the parsimony DIVA (Dispersal-vicariance analysis; Ronquist, 1997). This model was constructed by modelling DIVA's processes in order to restrict them to pre-established allowed schemes (widespread vicariance: yes; subset sympatry: no; see Ronquist \& Sanmartin, 2011 for details and explanation regarding DIVA). Also, j, was added, representing the relative per-event weight of founder-event/jump speciation events at cladogenesis events. The higher $\mathrm{j}$ is, the more probable these events are, and less probable are the standard cladogenesis events (Matzke, 2014). From the total events (9.52), 6.64 were founder events with anagenetic dispersal (1.52) and with vicariance (1.36) also playing a role. A Table with detailed information about the different dispersal models can be consulted at http://phylo.wdfiles.com/local--files/biogeobears/BioGeoBEARS_supermodel.png (accessed on 01 February 2018; see also Matzke, 2013a, 2013b, 2014).

Results of the isolation by distance test showed no significant correlation between genetic distance and geographic distance in any species $(p>0.05)$.

\section{Approximate time of divergence}

We calculated Bayes factors using Tracer v1.6 (Rambaut, Suchard, Xie, \& Drummond, 2014), comparing the likelihood and posteriors of the analyses using the strict and relaxed molecular clocks (Soares et al., 2013). Bayes factors indicated that a relaxed clock was more appropriate than a strict clock for the analysis (following Kass \& Raftery, 1995). The heterogeneity of the 
rates was evident in the estimated coefficient of variation of the evolutionary rate, that was $1.267(0.886-1.761,95 \%$ confidence interval), already on the verge of being too high for being consistent with the use of a clock (Drummond \& Bouckaert, 2015). The estimated mutation rate for the 5 priors' analysis (25\% burn-in) was $1.943 \%$ per Myr for COI (with a $1.750-2.150$ 95\% confidence interval). The COI-based divergence time estimates for all the MOTUs were higher than 9 Myr. The most recent estimated divergence was between MOTU 7 and MOTU 8: around $10 \mathrm{Myr}$ and the first and oldest split within D. edwardsi dated to around $36 \mathrm{Myr}$ (Figure 3). The divergence between $D$. magnitorata and $D$. bidentata was estimated at approximately $29 \mathrm{Myr}$ and the three species most likely shared a common ancestor more than 54 Myr b.p. (Figure 3). Figure S7 displays the analysis using the different models based on the rate alone and using either the islands' colonization priors or the paleontological calibration priors. It is clear that the paleontological calibration led to much older age estimates than the other three models (Figure S7A). The five priors' calibration displayed a more objective and weighted analysis and provided an estimate of the COI evolutionary rate clearly in line with previous estimates, independently of the divergent estimates provided by individual set of priors, and also resulting in an estimate with substantially narrower confidence intervals than the ones provided as a prior (Figure S7B). In this analysis (with 5 priors), the paleontological calibration was the one responsible for much older estimates on the coalescence of deeper lineages (on the genus and species' level) than on younger clades (islands' clades). Such an obtained feature of the relaxed clock, allowing a more rapid evolutionary rate for younger clades and a slower one for deep clades is very plausible, considering that it has been extensively demonstrated for the molecular clock of various markers and species (Ho et al., 2011).

\section{Discussion}

Here we report a new perspective on the drivers of evolution and underlying evolutionary mechanisms promoting diversification and segregation of marine invertebrates in the North 
Atlantic islands of Macaronesia. This new perspective resulted from the most comprehensive phylogeographic study to date applied to a larvae-lacking peracarid crustacean inhabiting this region. The archipelagos of Macaronesia harbour high genetic diversity within the morphospecies D. edwardsi (hereafter designated as the Dynamene edwardsi complex), comprising multiple, deeply divergent evolutionary lineages, geographically separated, and displaying high levels of island endemicity. Such findings would be anticipated in terrestrial organisms from oceanic islands, for whom the ocean constitutes a barrier to between-island dispersal, but are somewhat less expected in an intertidal marine invertebrate. Although the potential dispersal ability of $D$. edwardsi can be considered low compared to other invertebrates with planktonic larvae, no obvious geographic barriers can be identified that justify the lack of dispersal and effective migration between some geographically close populations (e.g., from as little as $50 \mathrm{~km}$ between Porto Santo and Madeira or between Tenerife and Gran Canaria); especially over the course of millions of years, since the establishment of founding populations. Alternative explanations must therefore be sought for the pronounced patterns of diversification observed.

\section{Re-appraisal of Dynamene diversity and incidence of cryptic species}

The diversity and distribution of the genus Dynamene in the Northern Hemisphere has been recently reviewed and updated (Vieira, Queiroga, Costa, \& Holdich, 2016). The revised information was based on morphology, as well as on new and published occurrence records, including the Macaronesian archipelagos. Just six species are known from the Northern Hemisphere and, among these, only three are found in the NE Atlantic: $D$. bidentata, $D$. magnitorata and D. edwardsi. Our findings, based on DNA sequence data from multiple mitochondrial and nuclear loci, challenge such assertions; the diversification reported here suggests the existence of at least seven Dynamene species in the NE Atlantic alone, and possibly up to nearly four times more species than are currently recognized in this oceanic region. 
The evidence for the striking diversification of Dynamene derives exclusively from molecular data and is essentially due to the $D$. edwardsi complex; notably, the species with the widest distribution in the Macaronesian islands. Combined and isolated data from the four-analysed mitochondrial DNA (mtDNA) and nuclear loci provide compelling evidence for the existence of at least five deeply divergent evolutionary units within the $D$. edwardsi complex, which have been genetically isolated for a long period (more than $9 \mathrm{Myr}$ and up to $36 \mathrm{Myr}$; Figure 3). Such entities likely coincide with recognition as separate species, at least at a molecular level (De Queiroz, 2007). The five genetic lineages are completely sorted, consistently recognized as separate MOTUs in all loci, and geographically arranged in such a way that, within the same island, only one lineage is represented at most, thus excluding any indication of occurrence of sympatric speciation.

The number of recognizable sorted lineages and MOTUs within the $D$. edwardsicomplex were variable, depending of the delimitation methods used, and whether the locus under consideration is a slow evolving nuclear gene (maximum five lineages), or a rapidly mutating mitochondrial gene (up to nine lineages). Lack of divergence or fixed substitutions in the nuclear loci between some of the lineages, which in turn are apparent with mtDNA, does not necessarily exclude the possibility that they represent separate cryptic species. Since rates of substitution are much slower in the nuclear loci, often highly divergent COI lineages (e.g., $>20 \%$ ) may coincide with very little differentiation in rDNA sequences (e.g., <1\%; Borges et al., 2012). In fact, both nuclear loci used here are notoriously known for poor species-level discrimination ability in many animal taxa (e.g., Jörger, Norenburg, Wilson, \& Schrödl, 2012), despite their robustness for reconstructing deeper phylogenies (e.g., Wetzer, Pérez-Losada, \& Bruce, 2013). Therefore, a combination of mitochondrial and nuclear multi-locus approach is advised to better assess species boundaries and unravel cryptic diversity (Grabowski, Wysocka, \& Mamos, 2017; Jörger \& Schrödl, 2013).

Taking COI data as a benchmark for comparison of genetic distances among crustacean species (Costa et al., 2007; Lobo et al., 2016), even the shortest distances between $D$. 
edwardsi complex MOTUs (3.79\%) would fall beyond the recorded distribution of intraspecific distances in numerous well established morphospecies, including this study's results for the other two congeneric species D. bidentata and D. magnitorata (maximum $1.54 \%$ and $2.65 \%$ respectively; Table 1). On the other hand, the highest average distance observed between the nine MOTUs within D. edwardsi complex (21.92\%) surpasses the average distance between $D$. bidentata and $D$. magnitorata (16.55\%). The range of $\mathrm{COI}$ genetic distances observed within the $D$. edwardsi complex are similar to values reported for a number of complexes of cryptic species of isopods, such as the Ligia occidentalis complex comprising 15 putative cryptic species with a divergence range of $13 \%$ to $27 \%$ (Markow \& Pfeiler, 2010); Excirolana braziliensis with three putative species, ranging from 14\% to 19\% (Varela \& Haye, 2012); Chelator insignis, five lineages with $>20 \%$ divergence (Brix, Svavarsson, \& Leese, 2014) and Sphaeroma terebrans with four distinct clades diverging from 15 to $18 \%$ (Baratti, Filippelli, \& Messana, 2011; Baratti, Goti, \& Messana, 2005).

\section{Phylogeography and evolution of the $\underline{D}$. edwardsi complex}

The extensive population structure revealed in the $D$. edwardsi complex was strongly reinforced by observed differences among regions in the AMOVA analysis (98.14\% - Table S6). Each MOTU was geographically delimited (Table S1), with the archipelagos of Madeira and Canaries comprising most of the diversity ( $80 \%$ of the total haplotypes). Moreover, the high recorded Fst values (Table S7) also suggest that gene flow is rare or absent among populations from different regions. This conjecture is further supported by the observed congruence in the lineage structure among different loci (Figures S1-5). Even though a lower number of specimens per MOTU was analysed for rRNA loci data compared with COI, the former has notably low intraspecific variation and hence sample size is not expected to impact the basal phylogenetic structure, nor the MOTU delimitation obtained with those loci (Borges et al., 2012). Indeed, as suggested by Bachtrog, Thornton, Clark, \& Andolfatto (2006), in 'ideal' systems like islands, under strict allopatry (i.e., no gene flow), all regions of the genome will have a single divergence history and vary only in their coalescence times. 
535 The complete genetic segregation of populations among most of the islands is therefore well

536 established, and originated over millions of years (spanning from a few Myr to possibly as 537 much as 50 Myr b.p.; Figure 3) until the present. Such patterns are unexpected due to the geographic proximity among many of the sampled populations. Although the dispersal ability of Dynamene specimens is thought to be fairly constrained, juveniles can be transported somewhat far from their birthplace by factors such as rough weather (Holdich, 1968b, 1970, 1976). Moreover, it is well documented that isopods can also be dispersed passively away from the coast (Ingólfsson \& Agnarsson, 2003; Thiel, 2002) through rafting on floating objects (usually detached macro algae; Scheltema, 1986; Thiel \& Gutow, 2005), via anthropogenic transfer (Kiessling, Gutow, \& Thiel, 2015; Rumbold et al., 2018) or, more rarely, if specimens remain attached to other species (Sponer \& Lessios, 2009), including marine birds (Frisch, Green, \& Figuerola, 2007). The occurrence of Dynamene species in a wide range of locations also confirms their dispersal capacity (Vieira, Queiroga, Costa, \& Holdich, 2016). However, the fact that we did not find MOTUs sharing the same island (i.e., within each morphospecies, namely $D$. edwardsi), suggests that any migrants, over geologically extended periods of millions of years, did not have the capacity to establish in locations where other populations/MOTUs were present, or, at least, that their genetic signature has been lost through genetic drift. Such an evolutionary phenomenon can occur by competitive exclusion, high density blocking (Waters, Fraser, \& Hewitt, 2013) or high mortality of physiologically stressed migrants (Barber, Palumbi, Erdmann, \& Moosa, 2002). Because Dynamene species require specific habitats to reproduce (e.g., barnacles or crevices), intense reproductive competition among Dynamene individuals is suspected (Holdich, 1976; Vieira, Queiroga, Costa, \& Holdich, 2016). The pattern observed in the D. edwardsi complex seems to fit the 'founder takes all' density-dependent process (Waters, Fraser, \& Hewitt, 2013), where the first founders rapidly colonize a new habitat, but subsequent migrants are incapable of successfully colonizing the pre-empted space. Pre-emptive competition occurs when a species recruits to and dominates a habitat, monopolizing all available space and precluding the establishment 
562

563

564

565

566

567

568

569

570

571

572

573

574

575

576

577

578

579

580

581

582

583

584

585

of potential competitors, i.e., when a species' reproductive ability relative to its longevity is higher than that of potential competitors (Amarasekare, Hoopes, Mouquet, \& Holyoak, 2004). Importantly, pre-emptive competition has also been invoked in structuring space-limited habitats such as the rocky intertidal (Dudgeon, Steneck, Davison, \& Vadas, 1999; Sutherland \& Karlson, 1977). Hence, the first colonist obtains an advantage over subsequent competitors. Successful exclusion then depends on the time lag before other immigrants arrive, growth rate of the resident population and local carrying capacity (De Meester, Vanoverbeke, Kilsdonk, \& Urban, 2016). Dispersal between coasts separated by deep-water over geological time-scales must have occurred (Cowie \& Holland, 2006) and, therefore, it seems remarkable that such discrete phylogeographic structure among islands was preserved apparently over millions of years. In such cases, it appears that the first lineage to colonize a new island has effectively excluded the secondary dispersers that must also have subsequently dispersed to the island. This phenomenon was previously described in marine (e.g., Barber, Palumbi, Erdmann, \& Moosa, 2000; Meyer \& Paulay, 2005; Waters, 2008) and terrestrial organisms (e.g., Cowie, 1992) over fine geographic scales, despite the lack of contemporary physical barriers. In fact, Dynamene isopods have relatively short life cycles which enable them to attain large census populations sizes in a short period (Holdich, 1968b, 1976). Our personal observations and population density estimates during quantitative sampling campaigns (specimen counts per unit of area) indicate that Macaronesia islands comprise very large census populations of Dynamene, in the order of thousands of specimens per site. Hence, even if a specimen or a brood from a foreign population could settle, it would be unlikely to affect and impact resident genetic pools of putatively high effective size.

It is noteworthy that no significant correlation was observed, either between geographic distance or island emergence time (data not shown) and the distribution of the multiple lineages of $D$. edwardsi complex. Dispersal episodes of this isopod probably occurred by accidental events associated with founder effects, suggesting that complex random patterns were the primary underlying mechanism of evolution. Such stochastic events have been suggested 
among various marine invertebrates in the Canaries and the Azores (e.g., Riel et al., 2005; Sá-

590 Pinto et al., 2008; Xavier et al., 2010). Within the D. edwardsi complex, the most interesting case of stochasticity is Madeira, whose haplotypes are very close to those of Tenerife, and embedded in the same MOTU (Figure 3). The island of Madeira emerged much more recently (around $5 \mathrm{Myr}$ ) than Tenerife (around $11 \mathrm{Myr}$ ) or Porto Santo islands (about $15 \mathrm{Myr}$ ago; see Fernández-Palacios et al., 2011; Geldmacher et al., 2005 for details), but it is located hundreds of kilometers away from Tenerife, whereas Porto Santo is located only $50 \mathrm{~km}$ away. Therefore, the Madeira population is likely to have originated from the Tenerife lineage through a relatively recent dispersal event that persisted, despite potential immigrant flow from the nearby Porto Santo lineage.

Macaronesian islands have been proposed as an offshore refugium for several marine organisms during the quaternary glaciations (e.g., Chevolot et al., 2006; Domingues, Almada, Santos, Brito, \& Bernardi, 2007; Domingues, Santos, Brito, \& Almada, 2006; Domingues, Stefanni, Brito, Santos, \& Almada, 2008; Xavier et al., 2010). These groups of islands appeared millions of years ago (see Fernández-Palacios et al., 2011; Fernández-Palacios \& Whittaker, 2008 for details), at different geological times and were shaped by the Pleistocene glaciations (2.58 Myr-present). During the Pleistocene, sea level changed several times and, more recently, raised more than 100 m (over the last 20,000 years; Mix, Bard, \& Schneider, 2001), submerging several islands that could have served as stepping stones in the past, namely the Paleo Madeira and Paleo Canaries (Ávila, 2000; Fernández-Palacios, Kueffer, \& Drake, 2015; Fernández-Palacios et al., 2011). Stepping stone colonizations are common in many terrestrial invertebrates in Macaronesia (reviewed by Juan, Emerson, Oromí, \& Hewitt, 2000) and such a scenario cannot be discarded for marine invertebrate species. Such processes may explain the relative genetic proximity of the $D$. edwardsipopulation from Porto Santo Island with those from the Iberian Peninsula, which seem to have separated around 5 Myr (Figure 3), before the last glaciation periods (Fernández-Palacios et al., 2011). How the change in sea surface temperature and sea level during quaternary glaciations, although small 
and gradual (Crowley, 1981; Santos, Hawkins, Monteiro, Alves, \& Isidro, 1995), affected marine (and coastal) populations is still not well understood (Barton et al., 1998; Cunha et al., 2014; Fernández-Palacios, 2016). It is probable that a combination of factors (e.g., littoral area, distance to continental coasts and island geological time) played a role in driving the observed evolution and the diversification of marine invertebrates in Macaronesia (see Ávila et al., 2018; Fernández-Palacios et al., 2016; Shaw \& Gillespie, 2016). However, in the case of the $D$. edwardsi complex, such factors appear to have little detectable impact on the observed deep phylogeographic footprint in a number of putatively cryptic species, which is better interpreted through alternative, though potentially complementary, mechanisms (e.g., 'founder takes all' density-dependent process).

\section{Final remarks}

The present study revealed twelve consistent MOTUs within the genus Dynamene in NE Atlantic, nine of which belong to the $D$. edwardsi complex and display an allopatric distribution. It is noteworthy that Dynamene is a genus with only six known species present in the Northern Hemisphere and just three in the NE Atlantic (Vieira, Queiroga, Costa, \& Holdich, 2016). If the putative cryptic species here reported are confirmed by further studies (e.g., ultrastructure or histological studies, geometric morphometry, ecology and behavior), it would represent a remarkable increase of $300 \%$ in known species diversity in the Northern Hemisphere for this species-poor genus. Moreover, since it is almost the case that each island holds its own putatively endemic cryptic species of $D$. edwardsi, this implies that each suspected species has a very narrow range and limited genetic diversity, and therefore constitute a particularly vulnerable species from the viewpoint of conservation (Pimm et al., 2014). If the evolutionary history of Macaronesia led to similar diversification processes in other peracarids (our unpublished data) or other marine invertebrates, there are novel and important implications to be considered in the coastal management and conservation strategies of such oceanic regions. Not only would the endemic diversity of marine invertebrates in the islands be much 
higher than previously recorded (i.e., Linnaean Shortfall), but also the design and planning of marine protected areas may need to contemplate the protection of island-specific marine biodiversity.

The segregation of cryptic species of $D$. edwardsi in Macaronesia islands have endured over millions of years, with clearly long-established divergence patterns. Complete lack of dispersal and migrants among islands over such a long period is highly unlikely. The patterns we observed are better explained by founder effects, followed by low survival and/or recruitment of posterior immigrants, due to genetic drift and density-driven exclusion in competition with the resident founder population. Such evolutionary mechanisms likely account for current diversity and distribution of the $D$. edwardsi complex in Macaronesia, in contrast with the oftenassumed processes for marine invertebrates, such as dispersal and connectivity, geographic distance and isolation. Priority effects of the type here illustrated may therefore provide an alternative explanation to the generation of deep segregation in the open ocean, and should be further investigated in other peracarids and marine invertebrate species present in oceanic islands.

\section{Acknowledgments}

The authors wish to thank the colleagues who helped during fieldwork and sample processing: Gomes N (University of Minho, Portugal), Tavares M, Santos R (University of Algarve, Portugal), Ladeiro B, Albuquerque R, Peteiro L, Gomes I, Guimarães B, Fuente N and Azevedo SL (University of Aveiro, Portugal). Thanks also to Marchini A and Sconfietti R (University of Pavia, Italy) for supplying Dynamene edwardsi specimens from Croatia and France. Additionally, thanks to Carvalho D and the Portuguese Museum of Natural History and Science, Lisbon for supplying material from EMEPC/M@rBis/Selvagens2010 and EMAM/PEPC_M@rBis/2011 campaigns to Selvagens. Acknowledgments also to Gomes N who contributed with lab work. Thanks to the Molecular Ecology and Fisheries Genetics 
Laboratory, Bangor University for hosting P.E.V. during the analysis of the data. We thank the anonymous reviewers for their insightful comments and suggestions.

671 This work is part of the research project DiverseShores - Testing associations between genetic 672 and community diversity in European rocky shore environments (PTDC/BIA673 BIC/114526/2009), funded by the Fundação para a Ciência e Tecnologia (FCT) under the 674 COMPETE program, supported by the European Regional Development Fund. FCT also 675 supported a Ph. D. grant to P.E.V. (SFRH/BD/86536/2012). Conselho Nacional de 676 Desenvolvimento Científico e Tecnológico (CNPq) provided a Ph. D. grant to A.D. (process 677 No 141565/2017-9). CBMA (P.E.V., P.S. and F.O.C.) contribution was supported by the 678 strategic programme UID/BIA/04050/2019, funded by national funds through the FCT I.P.

679

\section{Data Accessibility}

681 All DNA sequences produced in the scope of this study were deposited in BOLD and submitted 682 to GenBank. All data are publicly available through the BOLD dataset DS-DYNAMENE 683 (dx.doi.org/10.5883/DS-DYNAMENE).

684

685 686 687 688 689 690 691 692 693
DNA sequences of Dynamene specimens before alignment using Clustal W and subsequent removal of poorly aligned positions and divergent regions in rRNA sequences with Gblocks can be accessed at https://doi.org/10.5281/zenodo.1464764.

\section{Author Contributions}

P.E.V., D.M.H., F.O.C. and H.Q. designed the research plan; P.E.V. and D.M.H. performed the research; P.E.V., A.D. and P.S. analysed the data in collaboration with S.C. and G.R.C; P.E.V., F.O.C., H.Q., S.C. and G.R.C. wrote the paper; all the authors contributed with suggestions to the manuscript structure and reviewed the manuscript final version. 


\section{References}

Amarasekare, P., Hoopes, M. F., Mouquet, N., \& Holyoak, M. (2004). Mechanisms of coexistence in competitive metacommunities. The American Naturalist, 164(3), 310-326. doi:10.1086/422858

Ávila, S. P. (2000). Shallow-water marine molluscs of the Azores: biogeographical relationships. (Arquipélago. Life and Marine Sciences;Supl. 2A). Universidade dos Açores.

Ávila, S. P., Cordeiro, R., Madeira, P., Silva, L., Medeiros, A., Rebelo, A. C., ... Johnson, M. E. (2018). Global change impacts on large-scale biogeographic patterns of marine organisms on Atlantic oceanic islands. Marine Pollution Bulletin, 126, 101-112. doi:10.1016/J.MARPOLBUL.2017.10.087

Bachtrog, D., Thornton, K., Clark, A., \& Andolfatto, P. (2006). Extensive introgression of mitochondrial DNA relative to nuclear genes in the Drosophila yakuba species group. Evolution; International Journal of Organic Evolution, 60(2), 292-302.

Bandelt, H. J., Forster, P., Sykes, B. C., \& Richards, M. B. (1995). Mitochondrial portraits of human populations using median networks. Genetics, 141(2), 743-53.

Baratti, M., Filippelli, M., \& Messana, G. (2011). Complex genetic patterns in the mangrove wood-borer Sphaeroma terebrans Bate, 1866 (Isopoda, Crustacea, Sphaeromatidae) generated by shoreline topography and rafting dispersal. Journal of Experimental Marine Biology and Ecology, 398(1-2), 73-82. doi:10.1016/j.jembe.2010.12.008

Baratti, M., Goti, E., \& Messana, G. (2005). High level of genetic differentiation in the marine isopod Sphaeroma terebrans (Crustacea: Isopoda: Sphaeromatidae) as inferred by mitochondrial DNA analysis. Journal of Experimental Marine Biology and Ecology, 315(2), 225-234. doi:10.1016/j.jembe.2004.09.020

Barber, P. H., Palumbi, S. R., Erdmann, M. V., \& Moosa, M. K. (2000). A marine Wallace's line? Nature, 406(6797), 692-693. doi:10.1038/35021135

Barber, P. H., Palumbi, S. R., Erdmann, M. V, \& Moosa, M. K. (2002). Sharp genetic breaks among populations of Haptosquilla pulchella (Stomatopoda) indicate limits to larval transport: patterns, causes, and consequences. Molecular Ecology, 11(4), 659-74.

Barton, E. D., Aristegui, J., Tett, P., Canton, M., García-Braun, J., Hernández-León, S., ... Wild, K. (1998). The transition zone of the Canary Current upwelling region. Progress in Oceanography, 41(4), 455-504. doi:10.1016/S0079-6611(98)00023-8

Beheregaray, L. B., \& Caccone, A. (2007). Cryptic biodiversity in a changing world. Journal of Biology, 6(4), 9. doi:10.1186/jbiol60

Borges, L. M. S., Sivrikaya, H., le Roux, A., Shipway, J. R., Cragg, S. M., \& Costa, F. O. (2012). Investigating the taxonomy and systematics of marine wood borers (Bivalvia:Teredinidae) combining evidence from morphology, DNA barcodes and nuclear locus sequences. Invertebrate Systematics, 26(5-6), 572. doi:10.1071/IS12028

Borges, P.A.V., Amorim, I. R., Terzopoulou, S., Rigal, F., Emerson, B. C., \& Serrano, A. R. M. (2017). Cryptic diversity in Azorean beetle genus Tarphius Erichson, 1845 (Coleoptera: Zopheridae): An integrative taxonomic approach with description of four new species. Zootaxa, 4236, 401449. doi:10.11646/zootaxa.4236.3.1

Borregaard, M. K., Amorim, I. R., Borges, P. A. V., Cabral, J. S., Fernández-Palacios, J. M., Field, R., ... Whittaker, R. J. (2017). Oceanic island biogeography through the lens of the General Dynamic Model: assessment and prospect. Biological Reviews, 92, 830-853. doi:10.1111/brv.12256

Bouckaert, R., Heled, J., Kühnert, D., Vaughan, T., Wu, C.-H., Xie, D., ... Drummond, A. J. (2014). BEAST 2: a software platform for Bayesian evolutionary analysis. PLoS Computational Biology, 10(4), e1003537. doi:10.1371/journal.pcbi.1003537

Brix, S., Svavarsson, J., \& Leese, F. (2014). A multi-gene analysis reveals multiple highly divergent lineages of the isopod Chelator insignis (Hansen, 1916) south of Iceland. Polish Polar Research, 35(2), 225-242. doi:10.2478/popore

Cardoso, P., Erwin, T. L., Borges, P. A. V., \& New, T. R. (2011). The seven impediments in invertebrate conservation and how to overcome them. Biological Conservation, 144:2647-2655 (2011). The seven impediments in invertebrate conservation and how to overcome them. Biological Conservation, 144: 2647-2655. doi: 0.1016/j.biocon.2011.07.024

Carine, M. A., \& Schaefer, H. (2010). The Azores diversity enigma: Why are there so few Azorean endemic flowering plants and why are they so widespread? Journal of Biogeography, 37(1), 7789. doi:10.1111/j.1365-2699.2009.02181.x

Carracedo, J. C. (2011). Geología de Canarias. I, Origen, evolución, edad y volcanismo. Rueda. 
Castresana, J. (2000). Selection of conserved blocks from multiple alignments for their use in phylogenetic analysis. Molecular Biology and Evolution, 17(4), 540-552. doi:10.1093/oxfordjournals.molbev.a026334

Cheng, J., Karambelkar, B., \& Xie, Y. (2018). leaflet: create interactive web maps with the JavaScript 'Leaflet' Library. R package version 2.0.1. https://CRAN.R-project.org/package=leaflet.

Chevolot, M., Hoarau, G., Rijnsdorp, A. D., Stam, W. T., \& Olsen, J. L. (2006). Phylogeography and population structure of thornback rays (Raja clavata L., Rajidae). Molecular Ecology, 15(12), 3693-3705. doi:10.1111/j.1365-294X.2006.03043.x

Cook, B. D., Page, T. J., \& Hughes, J. M. (2008). Importance of cryptic species for identifying "representative" units of biodiversity for freshwater conservation. Biological Conservation, 141(11), 2821-2831. doi:10.1016/j.biocon.2008.08.018

Costa, F. O., DeWaard, J. R., Boutillier, J., Ratnasingham, S., Dooh, R. T., Hajibabaei, M., \& Hebert, P. D. N. (2007). Biological identifications through DNA barcodes: the case of the Crustacea. Canadian Journal of Fisheries and Aquatic Sciences, 64(2), 272-295. doi:10.1139/f07-008

Cowie, R. H. (1992). Evolution and extinction of Partulidae, endemic Pacific island land snails. Philosophical Transactions: Biological Sciences. doi:10.2307/55580

Cowie, R. H., \& Holland, B. S. (2006). Dispersal is fundamental to biogeography and the evolution of biodiversity on oceanic islands. Journal of Biogeography, 33(2), 193-198. doi:10.1111/j.13652699.2005.01383.x

Crowley, T. J. (1981). Temperature and circulation changes in the eastern North Atlantic during the last 150,000 years: evidence from the planktonic foraminiferal record. Marine Micropaleontology, 6 , 97-129.

Cunha, R. L., Lima, F. P., Tenorio, M. J., Ramos, A. A., Castilho, R., \& Williams, S. T. (2014). Evolution at a different pace: Distinctive phylogenetic patterns of cone snails from two ancient oceanic archipelagos. Systematic Biology, 63(6), 971-987. doi:10.1093/sysbio/syu059

Darwin, C. (1859). On the Origin of Species by Means of Natural Selection or the Preservation of Favoured Races in the Struggle for Life. London, UK: John Murray.

De Queiroz, K. (2007). Species concepts and species delimitation. Systematic Biology, 56(6), 879-886. doi:10.1080/10635150701701083

De Meester, L., Vanoverbeke, J., Kilsdonk, L. J., \& Urban, M. C. (2016). Evolving perspectives on monopolization and priority effects. Trends in Ecology \& Evolution, 31(2), 136-146. doi:10.1016/j.tree.2015.12.009

Diniz-Filho, J. A. F., Loyola, R. D., Raia, P., Mooers, A. O., \& Bini, L. M. (2013). Darwinian shortfalls in biodiversity conservation. Trends in Ecology \& Evolution, 28(12), 689-695. doi: 10.1016/j.tree.2013.09.003

Domingues, V. S., Almada, V. C., Santos, R. S., Brito, A., \& Bernardi, G. (2007). Phylogeography and evolution of the triplefin Tripterygion delaisi (Pisces, Blennioidei). Marine Biology, 150(3), 509519. doi:10.1007/s00227-006-0367-4

Domingues, V. S., Santos, R. S., Brito, A., \& Almada, V. C. (2006). Historical population dynamics and demography of the eastern Atlantic pomacentrid Chromis limbata (Valenciennes, 1833). Molecular Phylogenetics and Evolution, 40(1), 139-147. doi:10.1016/j.ympev.2006.02.009

Domingues, V. S., Stefanni, S., Brito, A., Santos, R. S., \& Almada, V. C. (2008). Phylogeography and demography of the Blenniid Parablennius parvicornis and its sister species $P$. sanguinolentus from the northeastern Atlantic Ocean and the western Mediterranean Sea. Molecular Phylogenetics and Evolution, 46(1), 397-402. doi:10.1016/j.ympev.2007.05.022

Drummond, A. J. \& Bouckaert, R. R. (2015). Bayesian evolutionary analysis with BEAST. Cambridge University Press.

Dudgeon, S. R., Steneck, R. S., Davison, I. R., \& Vadas, R. L. (1999). Coexistence of similar species in a space-limited intertidal zone. Ecological Monographs, 69(3), 331-352. doi:10.1890/00129615(1999)069[0331:COSSIA]2.0.CO;2

Emerson, B. C. (2002). Evolution on oceanic islands: molecular phylogenetic approaches to understanding pattern and process. Molecular Ecology, 11(6), 951-966. doi:10.1046/j.1365294X.2002.01507.x

Excoffier, L., \& Lischer, H. E. L. (2010). Arlequin suite ver 3.5: a new series of programs to perform population genetics analyses under Linux and Windows. Molecular Ecology Resources, 10(3), 564-567. doi:10.1111/j.1755-0998.2010.02847.x

Ezard, T., Fujisawa, T., \& Barraclough, T. (2009). SPLITS: species' limits by threshold statistics. R package version 1.0-18/ r45. Available at: http://R-Forge.R-project.org/projects/splits/. 
Fernández-Palacios, J. M. (2016). Island biogeography: shaped by sea-level shifts. Nature, 532(7597), 42-3. doi:10.1038/nature17880

Fernández-Palacios, J. M., Kueffer, C., \& Drake, D. R. (2015). A new golden era in island biogeography. Frontiers of Biogeography, 7(1), 14-20. doi:10.5811/westjem.2011.5.6700

Fernández-Palacios, J. M., Nascimento, L., Otto, R., Delgado, J. D., García-del-Rey, E., Arévalo, J. R., \& Whittaker, R. J. (2011). A reconstruction of Palaeo-Macaronesia, with particular reference to the long-term biogeography of the Atlantic island laurel forests. Journal of Biogeography, 38, 226-246. doi:10.1111/j.1365-2699.2010.02427.x

Fernández-Palacios, J. M., Rijsdijk, K. F., Norder, S. J., Otto, R., de Nascimento, L., Fernández-Lugo, S., ... Santos, A. (2016). Towards a glacial-sensitive model of island biogeography. Global Ecology and Biogeography, 25(7), 817-830. doi:10.1111/geb.12320

Fernández-Palacios, J. M., \& Whittaker, R. J. (2008). The Canaries: An important biogeographical meeting place. Journal of Biogeography, 35(3), 379-387. doi:10.1111/j.13652699.2008.01890.x

Fišer, C., Robinson, C. T., \& Malard, F. (2018). Cryptic species as a window into the paradigm shift of the species concept. Molecular Ecology, 27(3), 613-635. doi:10.1111/mec.14486

Folmer, O., Black, M., Hoeh, W., Lutz, R., \& Vrijenhoek, R. (1994). DNA primers for amplification of mitochondrial cytochrome $\mathrm{c}$ oxidase subunit I from diverse metazoan invertebrates. Molecular Marine Biology Biotechnology, 3, 294-299.

Frisch, D., Green, A. J., \& Figuerola, J. (2007). High dispersal capacity of a broad spectrum of aquatic invertebrates via waterbirds. Aquatic Sciences, 69(4), 568-574. doi:10.1007/s00027-007-09150

Fujisawa, T., \& Barraclough, T. G. (2013). Delimiting species using single-locus data and the generalized mixed yule coalescent approach: a revised method and evaluation on simulated data sets. Systematic Biology, 62(5), 707-724. doi:10.1093/sysbio/syt033

Geldmacher, J., Hoernle, K., Bogaard, P., Duggen, S., \& Werner, R. (2005). New ${ }^{40} \mathrm{~K} /{ }^{39} \mathrm{Ar}$ age and geochemical data from seamounts in the Canary and Madeira volcanic provinces: support for the mantle plume hypothesis. Earth and Planetary Science Letters, 237, 85-101. doi:10.1016/j.epsl.2005.04.037

Geldmacher, J., Hoernle, K., van den Bogaard, P., Zankl, G., \& Garbe-Schönberg, D. (2001). Earlier history of the $\geq 70$-Ma-old Canary hotspot based on the temporal and geochemical evolution of the Selvagen Archipelago and neighboring seamounts in the eastern North Atlantic. Journal of Volcanology and Geothermal Research, 111(1-4), 55-87. doi:https://doi.org/10.1016/S03770273(01)00220-7

Geller, J. B., Walton, E. D., Grosholz, E. D., \& Ruiz, G. M. (1997). Cryptic invasions of the crab Carcinus detected by molecular phylogeography. Molecular Ecology, 6(10), 901-906. doi:10.1046/j.1365-294X.1997.00256.X

Grabowski, M., Wysocka, A., \& Mamos, T. (2017). Molecular species delimitation methods provide new insight into taxonomy of the endemic gammarid species flock from the ancient Lake Ohrid. Zoological Journal of the Linnean Society, 181(2), 272-285. doi:10.1093/zoolinnean/zlw025

Grantham, B. A., Eckert, G. L., \& Shanks, A. L. (2003). Dispersal potential of marine invertebrates in diverse habitats. Ecological Applications, 13 Supplement(1), S108-S116.

Guillou, H., Carracedo, J. ., \& Duncan, R. . (2001). K-Ar, ${ }^{40} \mathrm{Ar}-39 \mathrm{Ar}$ ages and magnetostratigraphy of Brunhes and Matuyama lava sequences from La Palma Island. Journal of Volcanology and Geothermal Research, 106(3-4), 175-194. doi:10.1016/S0377-0273(00)00294-8

Guindon, S., Dufayard, J.-F., Lefort, V., Anisimova, M., Hordijk, W., \& Gascuel, O. (2010). New algorithms and methods to estimate maximum-likelihood phylogenies: assessing the performance of PhyML 3.0. Systematic Biology, 59(3), 307-321. doi:10.1093/sysbio/syq010

Hachich, N. F., Bonsall, M. B., Arraut, E. M., Barneche, D. R., Lewinsohn, T. M., \& Floeter, S. R. (2015). Island biogeography: patterns of marine shallow-water organisms in the Atlantic Ocean. Journal of Biogeography, 42(10), 1871-1882. doi:10.1111/jbi.12560

Highsmith, R. (1985). Floating and algal rafting as potential dispersal mechanisms in brooding invertebrates. Marine Ecology Progress Series, 25, 169-179. doi:10.3354/meps025169

Holdich, D. (1968a). A systematic revision of the genus Dynamene (Crustacea: Isopoda) with description of three new species. Pubblicazioni della Stazione Zoologica di Napoli, 36, 401-426.

Holdich, D. (1968b). Reproduction, growth and bionomics of Dynamene Bidentata (Crustacea Isopoda). Journal of Zoology, 156, 137-153.

Holdich, D. (1970). The distribution and habitat preferences of the Afro-European species of Dynamene 
(Crustacea: Isopoda). Journal of Natural History, 4(3), 419-438. doi:10.1080/00222937000770401

Holdich, D. (1976). A comparison of the ecology and life cycles of two species of littoral isopod. Journal of Experimental Marine Biology and Ecology, 24, 133-149.

Ho, S. Y. W., Lanfear, R., Bromham, L., Phillips, M. J., Soubrier, J., Rodrigo, A. G., \& Cooper, A. (2011). Time-dependent rates of molecular evolution. Molecular Ecology, 20(15), 3087-3101. doi: 10.1111/j.1365-294X.2011.05178.x

Ingólfsson, A., \& Agnarsson, I. (2003). Amphipods and isopods in the rocky intertidal: Dispersal and movements during high tide. Marine Biology, 143(5), 859-866. doi:10.1007/s00227-003-11326

Jensen, J. L., Bohonak, A. J., \& Kelley, S. T. (2005). Isolation by distance, web service. BMC Genetics, 6(13), 13. doi:doi: 10.1186/1471-2156-6-13

Jörger, K. M., Norenburg, J. L., Wilson, N. G., \& Schrödl, M. (2012). Barcoding against a paradox? Combined molecular species delineations reveal multiple cryptic lineages in elusive meiofaunal sea slugs. BMC Evolutionary Biology, 12, 245. doi:10.1186/1471-2148-12-245

Jörger, K. M., \& Schrödl, M. (2013). How to describe a cryptic species? Practical challenges of molecular taxonomy. Frontiers in Zoology, 10(1), 59. doi:10.1186/1742-9994-10-59

Juan, C., Emerson, B. C., Oromí, P., \& Hewitt, G. M. (2000). Colonization and diversification: towards a phylogeographic synthesis for the Canary Islands. Trends in Ecology \& Evolution, 15 (3), 104109. doi:10.1016/S0169-5347(99)01776-0

Kass, R. E., \& Raftery, A. E. (1995). Bayes Factors. Journal of the American Statistical Association, 90(430), 773. doi:10.2307/2291091

Ketmaier, V., Argano, R., \& Caccone, A. (2003). Phylogeography and molecular rates of subterranean aquatic Stenasellid Isopods with a peri-Tyrrhenian distribution. Molecular Ecology, 12(2), 547555. doi:10.1046/j.1365-294X.2003.01734.x

Khalaji-Pirbalouty, V., \& Raupach, M. J. (2014). A new species of Cymodoce Leach, 1814 (Crustacea: Isopoda: Sphaeromatidae) based on morphological and molecular data, with a key to the Northern Indian Ocean species. Zootaxa, 3826(1), 230-254. doi:10.11646/zootaxa.3826.1.7

Kiessling, T., Gutow, L., \& Thiel, M. (2015). Marine litter as habitat and dispersal vector. Marine Anthropogenic Litter ,141-181. doi:10.1007/978-3-319-16510-3_6

Knowlton, N. (1993). Sibling species in the sea. Annual Review of Ecology and Systematics, 24, 189216. doi: $10.2307 / 2097177$

Knowlton, N., \& Weigt, L. (1998). New dates and new rates for divergence across the Isthmus of Panama. Proceedings of the Royal Society B: Biological Sciences, 265, 2257-2263. doi: $10.1098 / \mathrm{rspb} .1998 .0568$

Konec, M., Prevorčnik, S., Sarbu, S. M., Verovnik, R., \& Trontelj, P. (2015). Parallels between two geographically and ecologically disparate cave invasions by the same species, Asellus aquaticus (Isopoda, Crustacea). Journal of Evolutionary Biology, 28(4), 864-875. doi:10.1111/jeb.12610

Kumar, S., Stecher, G., \& Tamura, K. (2016). MEGA7: Molecular Evolutionary Genetics Analysis version 7.0 for bigger datasets. Molecular Biology and Evolution. doi:10.1093/molbev/msw054

Larsen, K. (2001). Morphological and molecular investigation of polymorphism and cryptic species in tanaid crustaceans: implications for tanaid systematics and biodiversity estimates. Zoological Journal of the Linnean Society, 131, 353-379. doi:10.1006/zjls.2000.0235

Larsen, K., \& Wilson, G. D. F. (1998). Tanaidomorphan systematics: is it obsolete? Journal of Crustacean Biology, 18(2), 346-362. Retrieved from http://www.jstor.org/stable/1549329

Librado, P., \& Rozas, J. (2009). DnaSP v5: a software for comprehensive analysis of DNA polymorphism data. Bioinformatics, 25(11), 1451-1452. doi:10.1093/bioinformatics/btp187

Lins, S. F. L., Ho, S. Y. W., Wilson, G. D. F., \& Lo, N. (2012) Evidence for Permo-Triassic colonization of the deep sea by isopods. Biology Letters, 8, 979-982. doi:10.1098/rsbl.2012.0774

Lobo, J., Costa, P. M., Teixeira, M. A. L., Ferreira, M. S. G., Costa, M. H., \& Costa, F. O. (2013). Enhanced primers for amplification of DNA barcodes from a broad range of marine metazoans. BMC Ecology, 13(34), 1-8. doi:10.1186/1472-6785-13-34

Lobo, J., Ferreira, M. S., Antunes, I. C., Teixeira, M. A. L., Borges, L. M. S., Sousa, R., ... Costa, F. O. (2016). Contrasting morphological and DNA barcode suggested species boundaries among shallow-water amphipod fauna from the southern European Atlantic coast. Genome, 60(2): 147157. doi:10.1139/gen-2016-0009

López, H., Hernández-Teixidor, D., Macías-Hernández , N., Juan, C., \& Oromí, P. (2013) A taxonomic 
revision and species delimitation of the genus Purpuraria Enderlein, 1929 (Orthoptera: Pamphagidae) using an integrative approach. Journal Zoological Systematics and Evolutionary Research, 51, 173-186. doi: 10.1111/jzs.12023

Machado, A., Rodríguez-Expósito, E., López, M., \& Hernández, M. (2017). Phylogenetic analysis of the genus Laparocerus, with comments on colonisation and diversification in Macaronesia (Coleoptera, Curculionidae, Entiminae). ZooKeys, 651, 1-77. doi:10.3897/zookeys.651.10097

Maggs, C., Castilho, R., Foltz, D., Henzler, C., Taimour, M. J., Kelly, J., ... Wares, J. (2008). Evaluating signatures of glacial refugia for North Atlantic benthic marine taxa. Ecology, 89(11), 108-122.

Markow, T. A., \& Pfeiler, E. (2010). Mitochondrial DNA evidence for deep genetic divergences in allopatric populations of the rocky intertidal isopod Ligia occidentalis from the eastern Pacific. Molecular Phylogenetics and Evolution, 56(1), 468-473. doi:10.1016/j.ympev.2009.12.002

Matzke, N. J. (2013a). BioGeoBEARS: BioGeography with Bayesian (and Likelihood) Evolutionary Analysis in R Scripts. $R$ Package, Version 0.2. Berkeley, CA: University of California, Berkeley.

Matzke, N. J. (2013b). Probabilistic historical biogeography: new models for founder-event speciation, imperfect detection, and fossils allow improved accuracy and model-testing. Frontiers of Biogeography, 5(4).

Matzke, N. J. (2014). Model selection in historical biogeography reveals that founder-event speciation is a crucial process in island clades. Systematic Biology, 63(6), 951-970. doi:10.1093/sysbio/syu056

Meyer, C. P., \& Paulay, G. (2005). DNA barcoding: error rates based on comprehensive sampling. PLoS Biology, 3(12), 1-10. doi:10.1371/journal.pbio.0030422

Miglietta, M. P., Faucci, A., \& Santini, F. (2011). Speciation in the sea: overview of the symposium and discussion of future directions. Integrative and Comparative Biology, 51(3), 449-455. doi:10.1093/icb/icr024

Miller, M. A., Pfeiffer, W., \& Schwartz, T. (2010). Creating the CIPRES Science Gateway for inference of large phylogenetic trees. Gateway Computing Environments Workshop (GCE), 14 Nov. 2010, New Orleans, LA. doi:10.1109/GCE.2010.5676129

Mix, A.C., Bard, E., Schneider, R. (2001). Environmental processes of the ice age: land, oceans, glaciers (EPILOG). Quaternary Science Reviews, 20, 627-657. doi: 10.1016/S0277-3791(00)00145-1

Monaghan, M. T., Wild, R., Elliot, M., Fujisawa, T., Balke, M., Inward, D. J., ... Vogler, A. P. (2009). Accelerated species inventory on Madagascar using coalescent-based models of species delineation. Systematic Biology, 58, 298-311. doi: 10.1093/sysbio/syp027

Norder, S.J., Proios, K., Whittaker, R. J., Alonso, M. R., Borges, P. A. V., Borregaard, M. K., ...Rijsdijk, K. F. (2018). Beyond the Last Glacial Maximum: Island endemism is best explained by longlasting archipelago configurations. Global Ecology and Biogeography. doi: 10.1111/geb.12835

Palumbi, S. R., Martin, A., Romano, S., McMillan, W. O., Stice, L., \& Grabowski, G. (2002). The simple fool's guide to PCR version 2. University of Hawaii, 96822(808), 1-45. doi:10.1186/s13620-0150060-3

Panova, M., Nygren, A., Jonsson, P. R., \& Leidenberger, S. (2016). A molecular phylogeny of the northeast Atlantic species of the genus Idotea (Isopoda) with focus on the Baltic Sea. Zoologica Scripta, 1-12. doi:10.1111/zsc. 12200

Pimm, S.L., Jenkins, C.N., Abell, R., Brooks, T.M., Gittleman, J.L., Joppa, L.N., ...Sexton, J.O. (2014). The biodiversity of species and their rates of extinction, distribution, and protection. Science, 344(6187):1246752. doi:10.1126/science.1246752.

Poore, G. C. B., \& Bruce, N. L. (2012). Global diversity of marine isopods (except Asellota and crustacean symbionts). PLOS ONE, 7(8). doi:10.1371/journal.pone.0043529

Pons, J., Barraclough, T. G., Gomez-Zurita, J., Cardoso, A. Duran, D. P., Hazell, S., ... Vogler, A. (2006). Sequence-based species delimitation for the DNA taxonomy of undescribed insects. Systematics Biology, 55, 595-609.

Poulakakis, N., \& Sfenthourakis, S. (2008). Molecular phylogeny and phylogeography of the Greek populations of the genus Orthometopon (Isopoda, Oniscidea) based on mitochondrial DNA sequences. Zoological Journal of the Linnean Society, 152(4), 707-715. doi:10.1111/j.10963642.2007.00378.x

Puillandre, N., Lambert, A., Brouillet, S., \& Achaz, G. (2012). ABGD, Automatic Barcode Gap Discovery for primary species delimitation. Molecular Ecology, 21(8), 1864-1877. doi:10.1111/j.1365294X.2011.05239.x

R Core Team (2018). R: A language and environment for statistical computing. R Foundation for Statistical Computing, Vienna, Austria. https://www.R-project.org/. 
Radulovici, A. E., Sainte-Marie, B., \& Dufresne, F. (2009). DNA barcoding of marine crustaceans from the Estuary and Gulf of St Lawrence: a regional-scale approach. Molecular Ecology Resources, 9(1), 181-187. doi:10.1111/j.1755-0998.2009.02643.x

Rambaut, A., Suchard, M., Xie, D., \& Drummond, A. (2014). Tracer v1.6, Available from http://beast.bio.ed.ac.uk/Tracer.

Ratnasingham, S., \& Hebert, P. D. N. (2013). A DNA-based registry for all animal species: the barcode index number (BIN) system. PloS One, 8(7), e66213. doi:10.1371/journal.pone.0066213

Raupach, M. J., Bininda-Emonds, O. R. P., Knebelsberger, T., Laakmann, S., Pfaender, J., \& Leese, F. (2014). Phylogeographical analysis of Ligia oceanica (Crustacea: Isopoda) reveals two deeply divergent mitochondrial lineages. Biological Journal of the Linnean Society, 112(1), 16-30. doi:10.1111/bij.12254

Raupach, M. J., \& Wägele, J. W. (2006). Distinguishing cryptic species in Antarctic Asellota (Crustacea: Isopoda) - a preliminary study of mitochondrial DNA in Acanthaspidia drygalskii . Antarctic Science, 18(2), 191. doi:10.1017/S0954102006000228

Riel, P. Van, Jordaens, K., Houtte, N. Van, Martins, A. M. F., Verhagen, R., \& Backeljau, T. (2005). Molecular systematics of the endemic Leptaxini (Gastropoda: Pulmonata) on the Azores islands. Molecular Phylogenetics and Evolution, 37(1), 132-143. doi:10.1016/j.ympev.2005.03.019.

Ronquist, F. (1997). Dispersal-vicariance analysis: a new approach to the quantification of historical biogeography. Systematic Biology, 46 (1): 195-203. doi: 10.1093/sysbio/46.1.195.

Ronquist, F. \& Sanmartin, I. (2011). Phylogenetic methods in biogeography. Annual Review of Ecology Evolution and Systematics, 42, 441-464. doi:10.1146/annurev-ecolsys-102209-144710.

Ronquist, F., Teslenko, M., van der Mark, P., Ayres, D. L., Darling, A., Höhna, S., ... Huelsenbeck, J. P. (2012). MrBayes 3.2: Efficient bayesian phylogenetic inference and model choice across a large model space. Systematic Biology, 61(3), 539-542. doi:10.1093/sysbio/sys029

Rumbold, C., Meloni, M., Doti, B., Correa, N., Albano, M., Sylvester, F., \& Obenat, S. (2018). Two new nonindigenous isopods in the Southwestern Atlantic: Simultaneous assessment of population status and shipping transport vector. Journal of Sea Research, 138, 1-7. doi:10.1016/J.SEARES.2018.04.008

Sá-Pinto, A., Branco, M., Sayanda, D., \& Alexandrino, P. (2008). Patterns of colonization, evolution and gene flow in species of the genus Patella in the Macaronesian Islands. Molecular Ecology, 17(2), 519-532. doi:10.1111/j.1365-294X.2007.03563.x

Santos, R., Hawkins, S., Monteiro, L., Alves, M., \& Isidro, E. (1995). Marine research, resources and conservation in the Azores. Aquatic Conservation: Marine and Freshwater Ecosystems, 5(4), 311-354. doi:10.1002/aqc.3270050406

Scheltema, R. S. (1986). On dispersal and planktonic larvae of benthic invertebrates: an eclectic overview and summary of problems. Bulletin of Marine Science, 39 (2)(33), 290-322.

Shaw, K. L., \& Gillespie, R. G. (2016). Comparative phylogeography of oceanic archipelagos: hotspots for inferences of evolutionary process. Proceedings of the National Academy of Sciences, 113(29), 7986-7993. doi:10.1073/pnas.1601078113

Soares, P., Abrantes, D., Rito, T., Thomson, N., Radivojac, P., Li, B., ... Pereira, L. (2013). Evaluating purifying selection in the mitochondrial DNA of various mammalian species. PLoS ONE, 8(3), e58993. doi:10.1371/journal.pone.0058993

Sponer, R., \& Lessios, H. a. (2009). Mitochondrial phylogeography of the intertidal isopod Excirolana braziliensis on the two sides of the Isthmus of Panama. Proceedings of the Smithsonian Contributions to the Marine Sciences Symposium, 38, 219-228.

Sutherland, J. P., \& Karlson, R. H. (1977). Development and stability of the fouling community at Beaufort, North Carolina. Ecological Monographs, 47(4), 425-446. doi:10.2307/1942176

Talavera, G., \& Castresana, J. (2007). Improvement of phylogenies after removing divergent and ambiguously aligned blocks from protein sequence alignments. Systematic Biology, 56(4), 56477. doi:10.1080/10635150701472164

Thiel, M. (2002). The zoogeography of algae-associated peracarids along the Pacific coast of Chile. Journal of Biogeography, 29(8), 999-1008. doi:10.1046/j.1365-2699.2002.00745.x

Thiel, M., \& Gutow, L. (2005). The ecology of rafting in the marine environment. II. The rafting organisms and community. Oceanography and Marine Biology, 43, 279-418.

Thompson, J. D., Higgins, D. G., \& Gibson, T. J. (1994). CLUSTAL W: improving the sensitivity of progressive multiple sequence alignment through sequence weighting, position-specific gap penalties and weight matrix choice. Nucleic Acids Research, 22(22), 4673-4680. 
Tomikawa, K., Kobayashi, N., Morino, H., \& Mawatari, S. F. (2007). New gammaroid family, genera and species from subterranean waters of Japan, and their phylogenetic relationships (Crustacea: Amphipoda). Zoological Journal of the Linnean Society, 149(4), 643-670. doi:10.1111/j.10963642.2007.00277.x

Valente, L. M., Etienne, R. S., \& Phillimore, A. B. (2014). The effects of island ontogeny on species diversity and phylogeny. Proceedings of the Royal Society B: Biological Sciences, 281(1784), 20133227. doi:10.1098/rspb.2013.3227

Varela, A. I., \& Haye, P. A. (2012). The marine brooder Excirolana braziliensis (Crustacea: Isopoda) is also a complex of cryptic species on the coast of Chile. Revista Chilena de Historia Natural, 85(4), 495-502. doi:10.4067/S0716-078X2013000100011

Verovnik, R., Sket, B., \& Trontelj, P. (2005). The colonization of Europe by the freshwater crustacean Asellus aquaticus (Crustacea: Isopoda) proceeded from ancient refugia and was directed by habitat connectivity. Molecular Ecology, 14(14), 4355-4369. doi:10.1111/j.1365294X.2005.02745.X

Vieira, P. E., Queiroga, H., Costa, F. O., \& Holdich, D. M. (2016). Distribution and species identification in the crustacean isopod genus Dynamene Leach, 1814 along the North East Atlantic-Black Sea axis. ZooKeys, 635, 1-29.

Wares, J. P., \& Cunningham, C. W. (2001). Phylogeography and historical ecology of the North Atlantic intertidal. Evolution; International Journal of Organic Evolution, 55(12), 2455-2469. doi:10.1111/i.0014-3820.2001.tb00760.x

Waters, J. M. (2008). Marine biogeographical disjunction in temperate Australia: historical landbridge, contemporary currents, or both? Diversity and Distributions, 14(4), 692-700. doi:10.1111/j.1472-4642.2008.00481.x

Waters, J. M., Fraser, C. I., \& Hewitt, G. M. (2013). Founder takes all: density-dependent processes structure biodiversity. Trends in Ecology \& Evolution, 28(2), 78-85. doi:10.1016/j.tree.2012.08.024

Wetzer, R., Pérez-Losada, M., \& Bruce, N. L. (2013). Phylogenetic relationships of the family Sphaeromatidae Latreille, 1825 (Crustacea: Peracarida: Isopoda) within Sphaeromatidea based on 18S-rDNA molecular data. Zootaxa, 3599(2), 161-177.

Whitting, M. F. (2002). Mecoptera is paraphyletic: multiple genes and phylogeny of Mecoptera and Siphonaptera. Zoologica Scripta, 31, 93-104.

Xavier, J. R., van Soest, R. W. M., Breeuwer, J. A. J., Martins, A. M. F., \& Menken, S. B. J. (2010). Phylogeography, genetic diversity and structure of the poecilosclerid sponge Phorbas fictitius at oceanic islands. Contributions to Zoology, 79(3), 119-129.

Xavier, R., Santos, A. M., Harris, D. J., Sezgin, M., Machado, M., \& Branco, M. (2012). Phylogenetic analysis of the north-east Atlantic and Mediterranean species of the genus Stenosoma (Isopoda, Valvifera, Idoteidae). Zoologica Scripta, 41(4), 386-399. doi:10.1111/j.1463-6409.2012.00537.x

Xavier, R., Zenboudji, S., Lima, F. P., Harris, D. J., Santos, A. M., \& Branco, M. (2011). Phylogeography of the marine isopod Stenosoma nadejda (Rezig, 1989) in North African Atlantic and western Mediterranean coasts reveals complex differentiation patterns and a new species. Biological Journal of the Linnean Society, 104(2), 419-431. doi:10.1111/j.1095-8312.2011.01718.x

Zhang, J., Kapli, P., Pavlidis, P., \& Stamatakis, A. (2013). A general species delimitation method with applications to phylogenetic placements. Bioinformatics, 29(22), 2869-2876. doi:10.1093/bioinformatics/btt499 
Table 1. Mean and maximum pairwise genetic distances within each Dynamene species and for each of the four analysed loci.

\begin{tabular}{lcccc}
\hline \multicolumn{1}{c}{ Species } & $\begin{array}{c}\text { COI mean/ } \\
\text { maximum }\end{array}$ & $\begin{array}{c}\text { 16S rRNA mean// } \\
\text { maximum }\end{array}$ & $\begin{array}{c}\text { 18S rRNA mean/ } \\
\text { maximum }\end{array}$ & $\begin{array}{c}\text { 28S rRNA mean/ } \\
\text { maximum }\end{array}$ \\
\hline Dynamene edwardsi & $0.1414 / 0.2192$ & $0.0829 / 0.1596$ & $0.0093 / 0.0236$ & $0.0117 / 0.0282$ \\
Dynamene bidentata & $0.0043 / 0.0154$ & $0.0018 / 0.0044$ & $0.0002 / 0.0036$ & $0.0000 / 0.0000$ \\
Dynamene magnitorata & $0.0074 / 0.0265$ & $0.0025 / 0.0047$ & $0.0052 / 0.0117$ & $0.0013 / 0.0064$
\end{tabular}

Table 2. Average pairwise distances between MOTUs (1 to 9 D. edwardsi; 10 D. bidentata and 11-12 D. magnitorata) for COI (lower diagonal) and 16S rRNA (upper diagonal). The mean COI pairwise distances within each MOTU are highlighted in bold in the diagonal.

\begin{tabular}{lccccccccc|c|c|c}
\hline & MOTU 1 & MOTU 2 & MOTU 3 & MOTU 4 & MOTU 5 & MOTU 6 & MOTU 7 & MOTU 8 & MOTU 9 & MOTU 10 & MOTU 11 & MOTU 12 \\
\hline MOTU 1 & $\mathbf{0 . 0 0 0 3}$ & 0.0304 & 0.0622 & 0.1314 & 0.1312 & 0.1356 & 0.1272 & 0.1292 & 0.1277 & 0.2884 & 0.2713 & 0.2699 \\
MOTU 2 & 0.1222 & $\mathbf{0 . 0 0 9 1}$ & 0.0631 & 0.1265 & 0.1263 & 0.1307 & 0.1200 & 0.1198 & 0.1228 & 0.2875 & 0.2775 & 0.2786 \\
MOTU 3 & 0.1506 & 0.1424 & $\mathbf{0 . 0 0 0 0}$ & 0.1378 & 0.1354 & 0.1419 & 0.1321 & 0.1333 & 0.1319 & 0.3002 & 0.2706 & 0.2692 \\
MOTU 4 & 0.1805 & 0.1727 & 0.1746 & $\mathbf{0 . 0 0 1 2}$ & 0.0267 & 0.0244 & 0.0501 & 0.0535 & 0.0453 & 0.2902 & 0.2709 & 0.2747 \\
MOTU 5 & 0.1846 & 0.1842 & 0.1772 & 0.0755 & $\mathbf{0 . 0 0 4 2}$ & 0.0155 & 0.0533 & 0.0556 & 0.0474 & 0.2920 & 0.2729 & 0.2767 \\
MOTU 6 & 0.1838 & 0.1930 & 0.1852 & 0.0909 & 0.1178 & $\mathbf{0 . 0 0 3 7}$ & 0.0555 & 0.0578 & 0.0497 & 0.2918 & 0.2727 & 0.2764 \\
MOTU 7 & 0.1717 & 0.1713 & 0.1747 & 0.1308 & 0.1404 & 0.1282 & $\mathbf{0 . 0 0 4 0}$ & 0.0207 & 0.0207 & 0.2910 & 0.2646 & 0.2635 \\
MOTU 8 & 0.1690 & 0.1730 & 0.1781 & 0.1438 & 0.1402 & 0.1302 & 0.0482 & $\mathbf{0 . 0 0 0 5}$ & 0.0379 & 0.2946 & 0.2661 & 0.2651 \\
MOTU 9 & 0.1776 & 0.1778 & 0.1732 & 0.1341 & 0.1414 & 0.1281 & 0.0408 & 0.0178 & $\mathbf{0 . 0 0 3 1}$ & 0.2909 & 0.2693 & 0.2683 \\
MOTU 10 & 0.2355 & 0.2343 & 0.2158 & 0.2115 & 0.2083 & 0.2223 & 0.2101 & 0.2207 & 0.2166 & $\mathbf{0 . 0 0 4 2}$ & 0.1074 & 0.1111 \\
\hline MOTU 11 & 0.2229 & 0.2258 & 0.2198 & 0.2079 & 0.2027 & 0.2174 & 0.2140 & 0.2159 & 0.2048 & 0.1658 & $\mathbf{0 . 0 0 6 4}$ & 0.0040 \\
MOTU 12 & 0.2204 & 0.2264 & 0.2234 & 0.2042 & 0.2061 & 0.2232 & 0.2110 & 0.2130 & 0.2023 & 0.1651 & 0.0227 & - \\
\hline
\end{tabular}




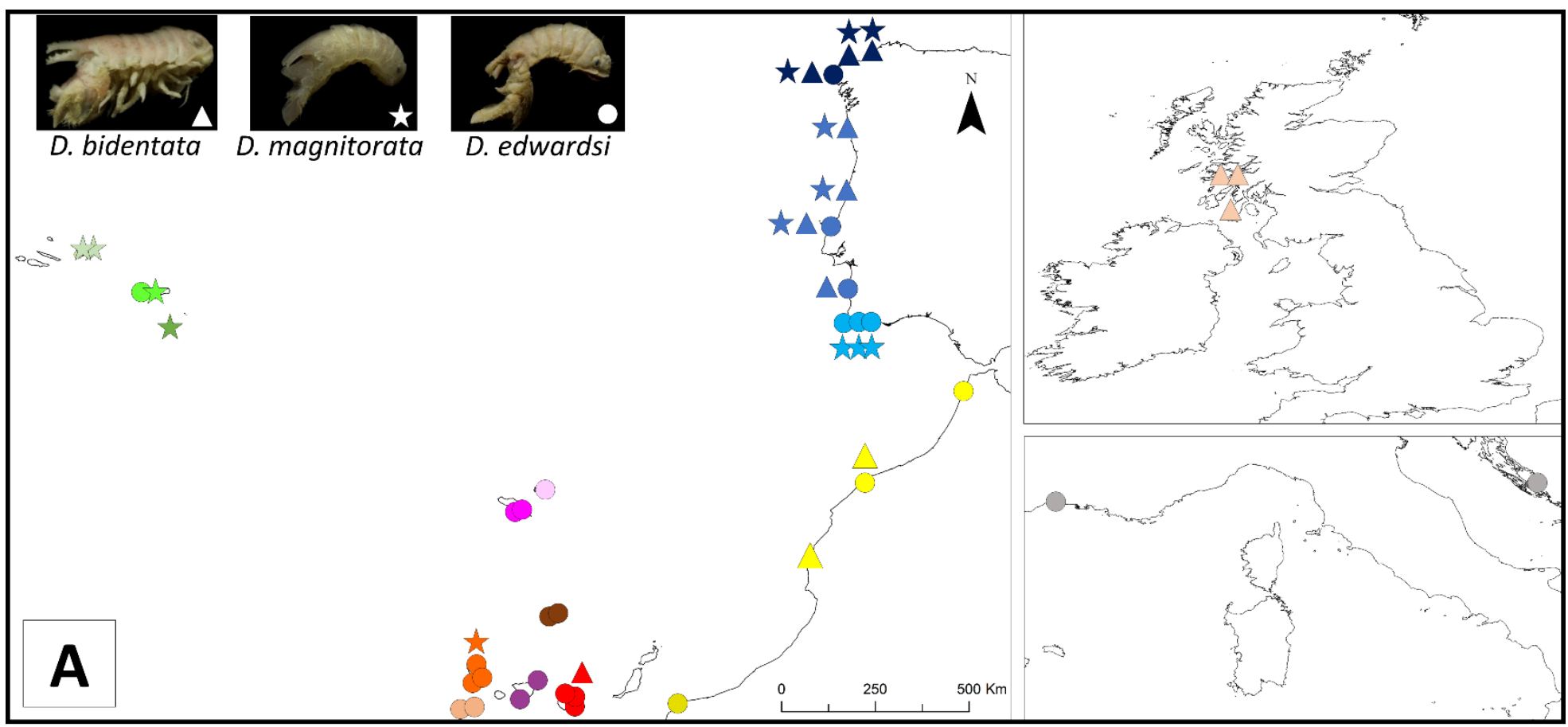

Geography:

$\square$ Scotland

Galicia

$\square$ Portugal West

Portugal South

Morocco North

Morocco South

Mediterranean

Terceira

Santa Maria

São Miguel

Madeira

Porto Santo

La Palma

Gran Canaria

Tenerife

El Hierro

Selvagens

D. magnitorata

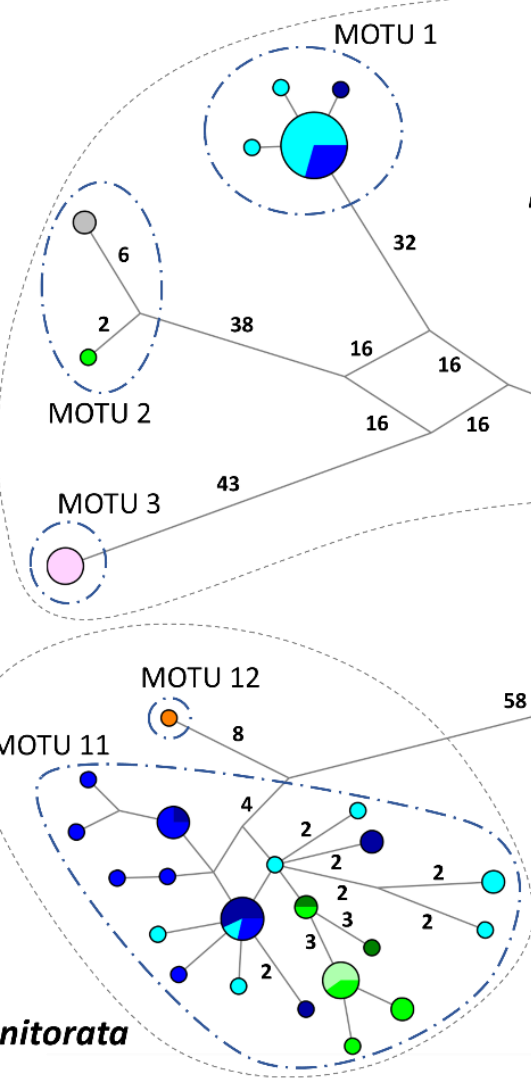

MOTU 6, - O O20;

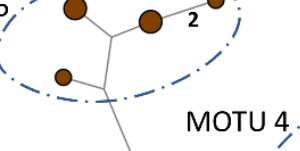

B

D. edwardsi

38
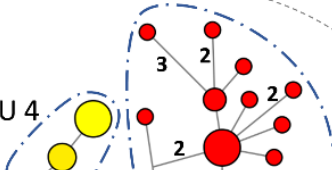

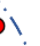

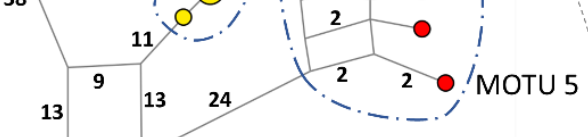

20

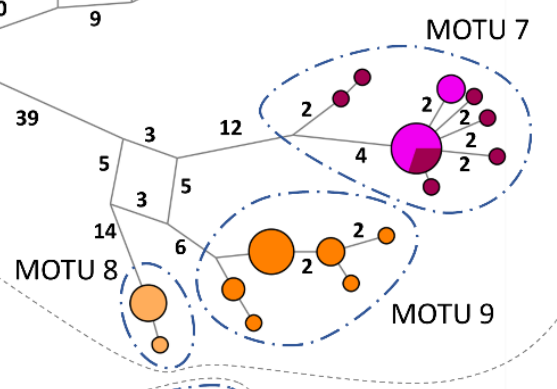

53

МОтU delimitation

Species delimitation

Figure 1. A. Sampling locations for each Dynamene species. B. Reduced median network based on COI datafor the Dynamene morphospecies. Size of the circles is proportional to the number of haplotypes. Number of mutations separating each haplotype and inferred ancestors (median vectors) are displayed in black. Mutation numbers not shown in links displaying a single mutation. 

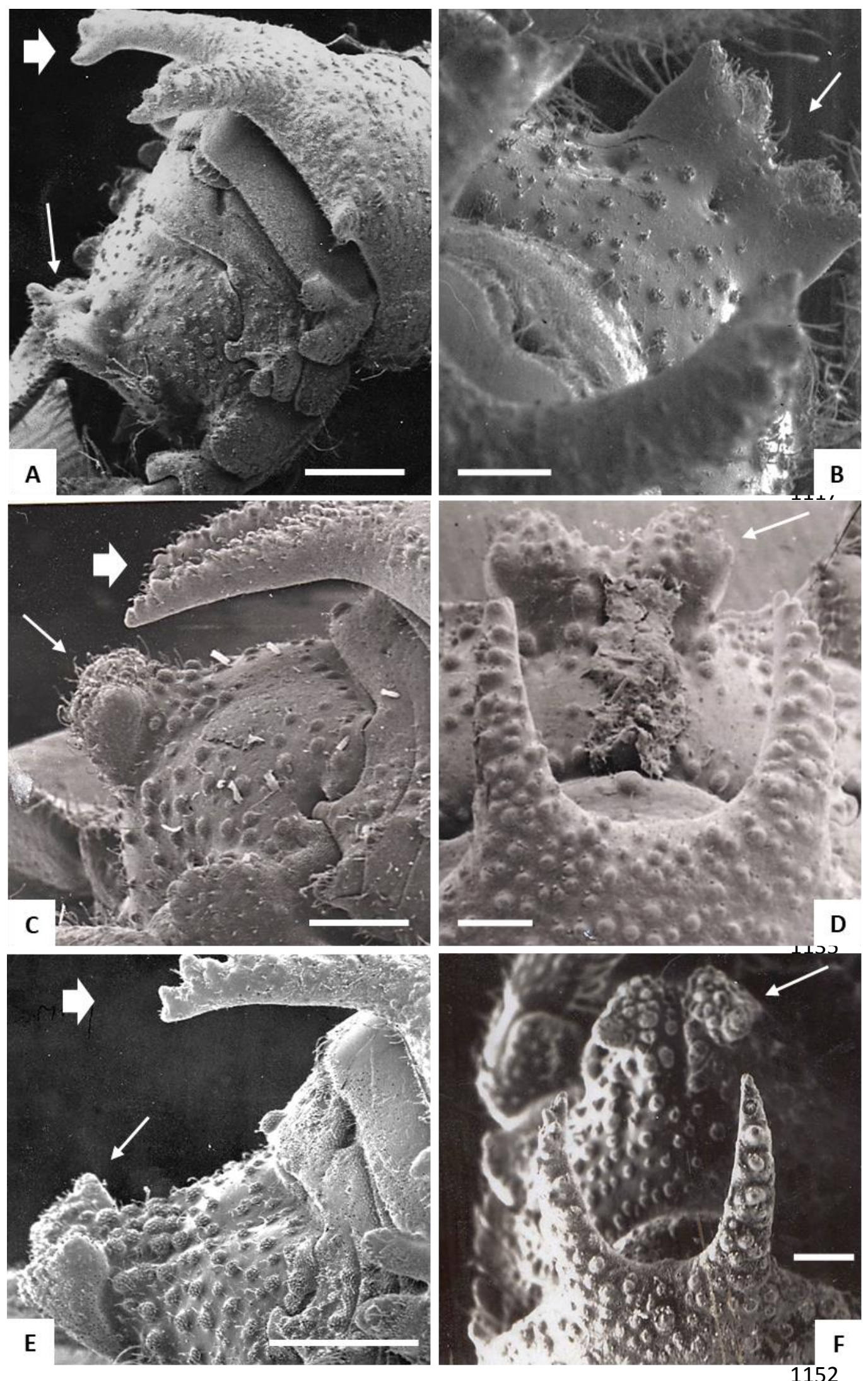

Figure 2. Stereoscan electronmicrographs of the three species of Dynamene showing differences in the posterior pereon and pleotelson. A - pereon and pleotelson of stage 8 male Dynamene edwardsi. B pleotelsonic boss in dorsal view. C - posterior pereon, and pleotelson of stage 8 male Dynamene bidentata. D - pleotelsonic boss in dorsal view. E - posterior pereon and pleotelson of stage 8 male Dynamene magnitorata. $\mathbf{F}$ - pleotelsonic boss in dorsal view. Scale bars of 0.5 and $0.1 \mathrm{~mm}$ respectively for left and right figures.

Adapted from Holdich (1976). 


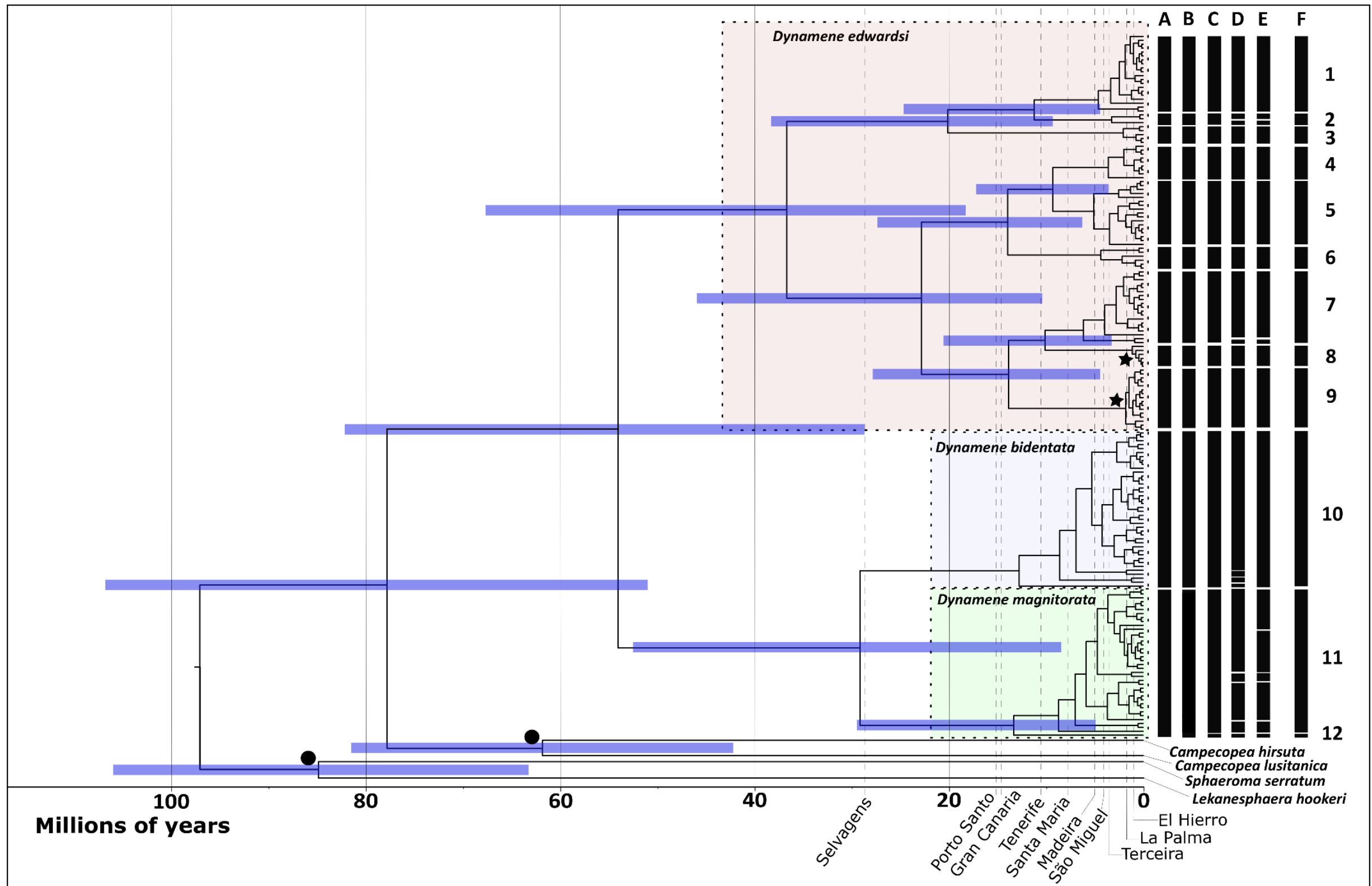

Figure 3. Bayesian, time-calibrated, phylogenetic reconstruction for the three Dynamene species, inferred from partial sequences (658 base pair) of the COI gene. For simplicity, only the outgroup species Campecopea hirsuta, C. Iusitanica, Sphaeroma serratum and Lekanesphaera hookeri are displayed (in Table S4, a full list of the outgroups used can be consulted). All nodes have Bayesian posterior probability values of 1.0 . Blue horizontal bars indicate $95 \%$ confidence intervals (within MOTUs not shown). Stars indicate islands' formation priors and circles the paleontological calibrations. Islands genesis also displayed in dashed lines. Vertical black bars correspond to MOTUs determined from COI sequence data by the following methods. A. BINs delimitation. B. bPTP analyses. C. ABGD analyses. D. GMYC single threshold analyses. E. GMYC multiple threshold analyses. F. Consensus MOTUs. 